\title{
Unraveling Field Crops Sensitivity to Heat Stress: Mechanisms, Approaches, and Future Prospects
}

\author{
Muhammad Nadeem ${ }^{\dagger}$, Jiajia Li ${ }^{\dagger}$, Minghua Wang, Liaqat Shah, Shaoqi Lu, Xiaobo Wang * \\ and Chuanxi Ma
}

School of Agronomy, Anhui Agricultural University, Hefei 230000, China; rananadeem.aaur@yahoo.com (M.N.); lijia6862@ahau.edu.cn (J.L.); minghuawang.ahua@gmail.com (M.W.); laqoo@yahoo.com (L.S.); 15102292@ahau.edu.cn (S.L.); machuanxi@ahau.edu.cn (C.M.)

* Correspondence: wangxiaobo@ahau.edu.cn; Tel.: +086-0551-6578-6209

+ These authors contributed equally to this work.

Received: 28 May 2018; Accepted: 20 July 2018; Published: 23 July 2018

\begin{abstract}
The astonishing increase in temperature presents an alarming threat to crop production worldwide. As evident by huge yield decline in various crops, the escalating drastic impacts of heat stress (HS) are putting global food production as well as nutritional security at high risk. HS is a major abiotic stress that influences plant morphology, physiology, reproduction, and productivity worldwide. The physiological and molecular responses to HS are dynamic research areas, and molecular techniques are being adopted for producing heat tolerant crop plants. In this article, we reviewed recent findings, impacts, adoption, and tolerance at the cellular, organellar, and whole plant level and reported several approaches that are used to improve HS tolerance in crop plants. Omics approaches unravel various mechanisms underlying thermotolerance, which is imperative to understand the processes of molecular responses toward HS. Our review about physiological and molecular mechanisms may enlighten ways to develop thermo-tolerant cultivars and to produce crop plants that are agriculturally important in adverse climatic conditions.
\end{abstract}

Keywords: heat stress; thermotolerance; oxidative stress; heat shock proteins; QTLs; plant omics

\section{Introduction}

In recent years, temperature extremes and weather disasters have partially or completely damaged regional crop production [1-3]. The annual worldwide temperature has been increasing steadily, and is expected to be increased by $1.8-4.0^{\circ} \mathrm{C}$ by the end of the 21st century [4]. This increasing trend in temperature creating curiosity among researchers, as temperature has an impact on life on earth, acting directly or indirectly. Regardless of these encounters, global food production will have to rise by $70 \%$ to meet the mandate of an expected rise in population growth to 9 billion by 2050 [5].

Plants as sessile organisms and cannot change their position or move to more suitable climatic conditions; therefore, plant activities are extensively affected by heat stress (HS), which often leads to mortally [6]. Specifically, HS has an impact on a number of various plant species [7]. HS significantly affect plant activities like seed germination, plant development, photosynthesis, and reproduction, which have a devastating impact on the overall yield of a crop [8]. It has been observed that HS leads to inhibition of pollen grain swelling leading to perturbed pollen dispersal and anther indehiscence during the reproductive process, which finally influence seed yield of rice [9]. Heat and drought are the key abiotic stresses to cereal crop production and resulted in the reduction of yield by $9 \%$ to $10 \%$ between 1964 and 2007 worldwide [2].

For survival in severe conditions, plants continuously struggle to modify their metabolic process in many ways in response to HS, specifically by generating key solutes that leads to establish proteins 
and osmotic adjustment and re-establish the redox balance of cell and homeostasis by modify the antioxidant system $[10,11]$. A plant in defense from HS causes modifications at the molecular level in the expression of genes [12]. In HS conditions, change in biochemical and physiological activities by gene expression alter gradually, resulting in the development of thermotolerance [13]. In order to successfully produce HS-tolerant crop varieties in the light of global climate change, there is need of knowledge and investigations about HS-tolerance mechanisms at physiological, biochemical, and molecular levels.

At present, investigations into selection strategy and breeding for thermotolerant cultivars and understanding of heat tolerance mechanisms are more required today than ever before. Molecular and genetic mechanisms for avoiding HS-induced harmful changes play a crucial role in plant survival under such circumstances. In the present scenario of global warming, the major challenge for plant scientists is to develop new crop varieties tolerant to HS [14]. In the coming years, agricultural production will have to deal with growing crops under sub-optimal conditions accompanied by increased food demand, creating a gap between the current yield achievements and yield potential [15]. Developing genetically modified plants through target genes manipulation, QTLs, and omics techniques are widely studied molecular approaches in recent years. Our study about sensitivity, adaptations, mechanisms, and approaches may uncover ways to develop thermo-tolerant cultivars and to produce crop plants that are agriculturally important in adverse climatic conditions.

\section{Plant Sensitivity to Heat Stress}

Plant sensitivity to HS varies with duration, plant type, and the degree of temperature. Plant growth and development are greatly influenced by the series of morphological, physiological, and biochemical changes resulting from HS [16]. HS cause devastating impacts on crop plants by affecting vital physiological functions, including protein denaturation, increase in membrane fluidity, level of reactive oxygen species (ROS), decline in photosystem II (PSII)-mediated electron transport, as well as inactivation of chloroplast and mitochondrial enzymes activities [17-19]. HS due to the rising global temperature is becoming one of the main limiting factor to crop productivity and has an adverse impact on plants (Figure 1). This rising temperature may cause a change in the morphology, physiology, and growing periods of plants.

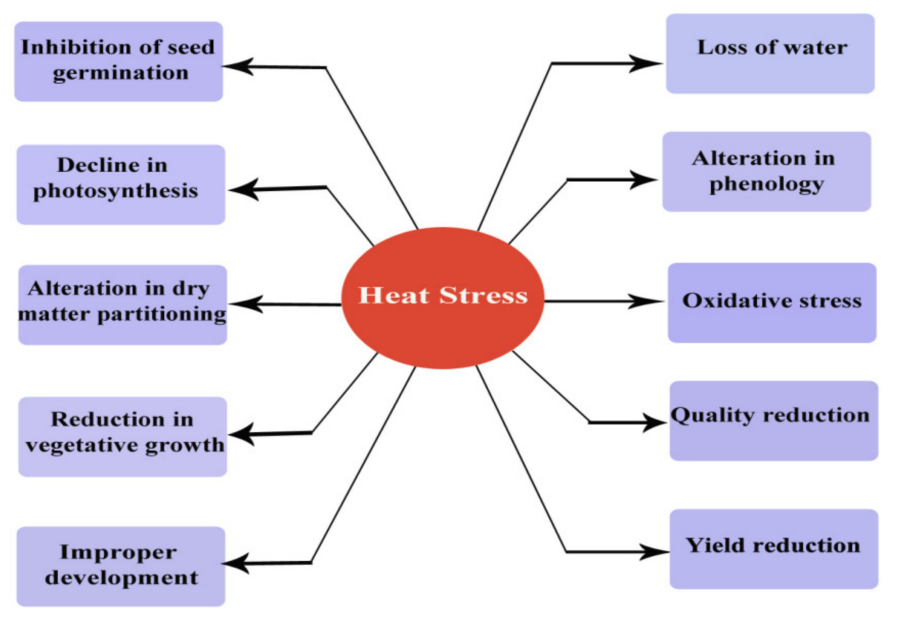

Figure 1. Impact of heat stress on plants.

\subsection{Morphological Responses}

\subsubsection{Crop Growth and Development}

During crop growth and development, temperature plays an important role in dry matter partitioning, transpiration [20,21], photosynthetic activity, respiration [22,23], and root and plant 
development [24]. The ideal conditions for plant growth and development generally occur within a different range of temperature [25], with low or high temperature (HT) reducing growth and developmental rates [26,27]. In winter cereals, temperature acts as a signal stimulator in processes of vernalization to induce flowering in plants [28]. It has been investigated that the increase in temperature to optimum thresholds stimulates biochemical mechanisms, consequently affecting development rates and declining the lengths of growing seasons [29]. The shorter developmental phases could have an adverse impact on the formation of yield components [30]. In Germany, between 1959 and 2009, lengths of growing seasons of oats reduced by about two weeks, leading to an earlier occurrence of phonological phases due to by HT [31]. As HT trigger development of the crop, the phases of crop growth duration decline, producing a destructive impact on yield in field crops and final grain weight [30]. It is observed that temperature has negative effect on growth and phototropism of Arabidopsis thaliana (L.) seedlings [32]. Van Der Ploeg and Heuvelink [33] reviewed the Influence of sub-optimal temperature on growth and yield of tomato. In a recent study, Yang et al. [34] investigated the effects of different growth temperatures on growth, development, and plastid pigments metabolism of tobacco (Nicotiana tabacum L.) plants.

\subsubsection{Reproductive Development}

HS has the widest and most far-reaching effects on plant reproductive organ, seed weight, and number of seeds, but regulation of heat-shock responses in inflorescence is largely uncharacterized [32,33]. It has been reported that male and female organs are most sensitive to extreme temperature, especially $\geq 30{ }^{\circ} \mathrm{C}[34]$ (Figure 2a). HS damages both male and female gametophytes, resulting in decreased pollen viability, reduced pollen germination, pollen tube growth inhibition, stigma receptivity reduction and reduced ovule function, declined fertilization, limited embryogenesis, poor ovule viability, enhanced ovule abortion, and a decrease in yield $[35,36]$ (Figure 2b).
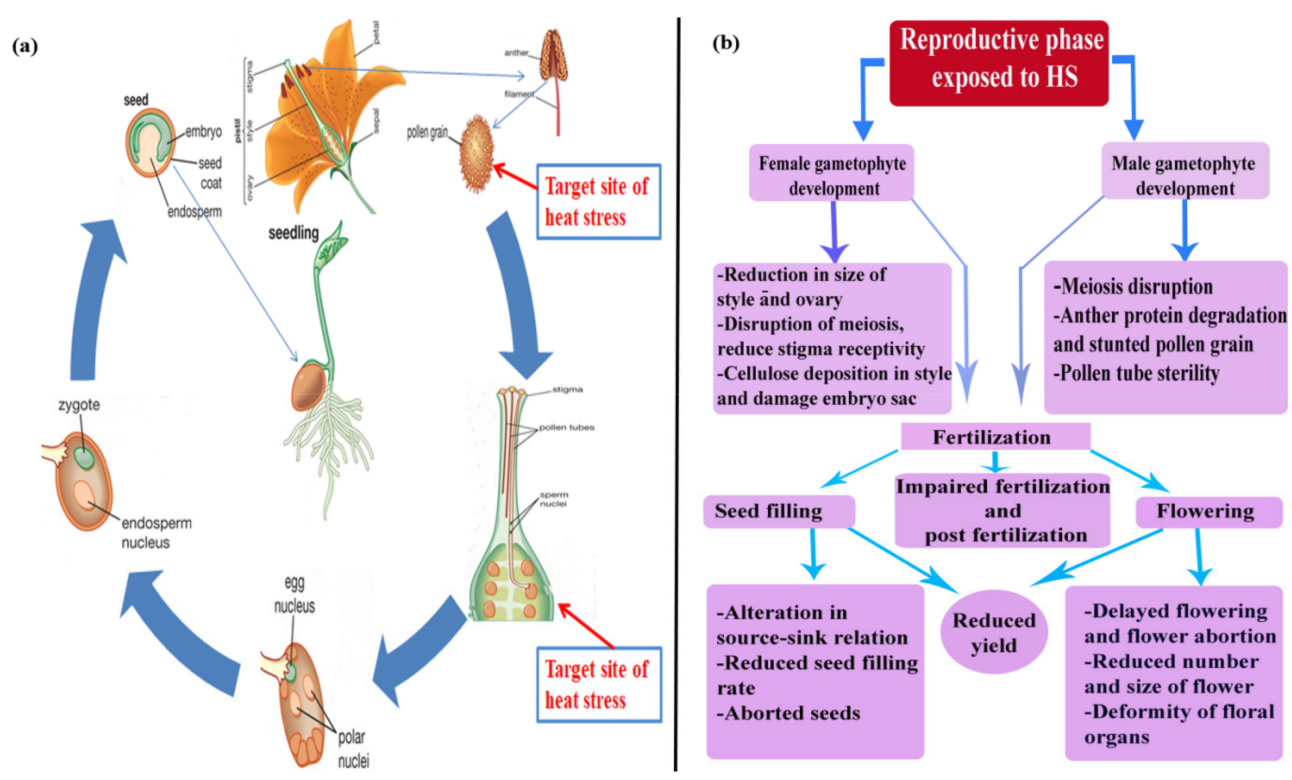

Figure 2. (a) Life cycle of an angiosperm representing target sites of heat stress (HS). Both male (pollen grains) and female (ovule) gametophytes are the main target sites of heat stress. (b) Sensitivity of reproductive phase to heat stress and consequences of heat stress on reproductive and grain-filling phases.

The number of seed year ${ }^{-1}$ increases with increasing air temperature from $16-28^{\circ} \mathrm{C}$, though it harshly declines with further increases in temperature [37]. During the period of grain filling, HS has a great impact on the quality and quantity of the final yield [38,39]. Enhancing temperatures from $25-31{ }^{\circ} \mathrm{C}$ increased the rates of grain filling, although the final yield steadily decreased due to shortening of the 
grain filling duration [40]. In wheat, at mean temperatures of $21 / 16^{\circ} \mathrm{C}$, the higher grain numbers are obtained [35]. It has been found that the increase in temperatures to crop-specific thresholds (for wheat $10-21^{\circ} \mathrm{C}$ ) enhance the rate of grain filling by enhancing cell-division rates in the tissue of endosperm and increasing rates of metabolism [41]. Dry matter partitioning, which is the product of the movement of photosynthetic assimilate from source-sink organs, is enhanced between $10-30{ }^{\circ} \mathrm{C}$ in winter-season cereals [42]. The devastating decrease in growth and development, harvest index (HI), and seed yield were found for various crops. The decline of grain number resulted from the impact of HT on meiosis and transfer of pollen during anthesis and ovaries growth during pre-anthesis periods. It has been reported that in pepper plants, HS resulted in a drop in sucrose concentration in fruits/flowers, though in cereals, sucrose helps the plant avoid ovary abortion under water stress conditions [43]. The reproductive phase is more sensitive to HS, and high temperatures are likely to coincide with anther dehiscence and gametophyte development, which resulted in a final yield reduction.

\subsubsection{Yield}

HS has an adverse impact on various processes of crop growth and development and final yield [44]. It has been reported that HS leads to yield losses in various crops [45] (Table 1). With a $1^{\circ} \mathrm{C}$ increase in global temperature, global wheat production is projected to decrease between $4.1 \%$ and $6.4 \%$ [46]. It is declared that the increase in temperature expected with environmental variability is likely to decrease wheat yields [47]. Additionally, in wheat, an annual worldwide yield loss of 19 million tons is observed, costing \$2.6 billion, due to climate variability from 1981 to 2002 [6]. Globally, temperature trend analysis from 1980 to 2008 has revealed about a 5.5\% decrease in the yield of wheat [1]. Similarly, it has been found that temperatures beyond $34{ }^{\circ} \mathrm{C}$ enhance the rates of senescence based on nine years of satellite data of wheat grown in northern India, thereby resulting in a significant reduction in yield [48].

Table 1. Yield reduction due to heat stress (HS) in some major crops.

\begin{tabular}{ccc}
\hline Crop & Yield Reduction (\%) & Reference \\
\hline Wheat (Triticum aestivum L.) & 31 & {$[49]$} \\
Maize (Zea mays L.) & 45 & {$[50]$} \\
Rice (Oryza sativa L.) & 50 & {$[51]$} \\
Soybean (Glycine max L.) & 46 & {$[52]$} \\
Canola (Brassica napus L.) & 50 & {$[53,54]$} \\
Peanut (Arachis hypogaea L.) & 31 & {$[55]$} \\
Srghumm (Sorghum bicolor L.) & 44 & {$[56]$} \\
Sunflower (Helianthus annuus L.) & 10 & {$[57]$} \\
\hline
\end{tabular}

In addition to wheat, in maize, thermal warming form 1981 to 2002 has triggered a reduction in yield up to 12 million tons year ${ }^{-1}$, comparable to a loss of $\$ 1.2$ billion [6]. By 2100, a reduction of yield of about $30 \%$ in maize is recorded in the US by means of the nonlinear temperature and yield analysis [52]. Similarly, about a 3.8\% yield loss in maize was observed by worldwide temperature trends analyses using past data from 1980 to 2008 [58]. These studies suggest that a rise in temperature beyond $30{ }^{\circ} \mathrm{C}$ have adverse effects on rainfed maize in Africa and the US [59]. It is reported that extreme HS at enthesis could reduce maize yield globally by $45 \%$ by 2080 as compared to the 1980 s [50].

In the case of soybean, a decline in yield of about $46 \%$ in the US before the year 2100 is predicted by non-linear and asymmetric temperature and yield relationship analyses [52]. It is reported that during 1976 to 2006 in the US, a future yield reduction of about $16 \%$ has been observed in soybean due to a change in patterns of temperature [60]. In barley, thermal warming from 1981 to 2002 caused a yield reduction of 8 million tons year ${ }^{-1}$, with loss of around $\$ 1$ billion [6]. Cucumber (Cucumis satious L.) is one of the most important horticultural crops and is highly sensitive to HS, particularly at the vegetative stage [61,62]. 


\subsection{Physiological Responses}

\subsubsection{Membrane Damage}

In a plant cell, the most sensitive component is the plasma membrane, as it is the primary sites of injury under HS [63]. HS severely affects the structure and functions of the membrane, thereby increasing membranes fluidity due to denaturation of proteins and increased level of unsaturated fatty acids, causing a transition from solid gel to flexible crystalline liquid structure [64]. HS damage can be assessed by loss of membrane integrity due to structural modifications of component proteins, which enhances the thermostability of the membrane and organic and inorganic ions leakage from the cells [65]. Therefore, an electrolyte leakage value acts as a pointer of membrane injury and reflects stress-induced alterations and has been used to evaluate the thermostability of membranes under HS [66]. The increased permeability and leakage of ions out of the cell has been used as a measure of cell membrane stability and as a screen test for HS tolerance [67]. The effects of HS on membranes have been reported in various crops. In cotton, sorghum, and soybean, HS-induced serious membrane injury and membrane lipid peroxidation have been observed $[51,68]$. The increased permeability of the membrane and electrolyte leakage is noticed under HS in soybeans, which declined the capacity of the plasma membrane to hold solutes and water [69]. Similarly, in chickpeas, injury of the membrane was noticed at $40 / 30{ }^{\circ} \mathrm{C}$, which was intensified at $45 / 35^{\circ} \mathrm{C}$, especially in sensitive genotypes [70]. A recent study investigated cell membrane stability under drought and heat conditions in wheat [67]. Membrane fluidity in temperature tolerance has been delineated by mutation analysis and transgenic and physiological studies. For instance, a soybean mutant deficient in fatty acid unsaturation exhibited high tolerance to HS [71]. Also, the thylakoid membranes of two Arabidopsis mutants deficient in fatty acid unsaturation (fad5 and fad6) exhibited increased stability to HS and increased lipid saturation in tobacco caused by silencing a $\omega-3$ desaturase gene, which also rendered the plants more tolerant to HS [72,73]. Wheat lines of high membrane thermal stability tended to yield higher than lines of low membrane thermostability when grain filling occurred under harsh climate [74]. It is investigated that HIT1 functions in the membrane trafficking that is involved in the thermal adaptation of the plasma membrane for tolerance to HS in plants [75]. In transgenic tobacco, overexpression of the PpEXP1 gene exhibited a less structural damage to cells, lower electrolyte leakage, and lower levels of membrane lipid peroxidation compared to wild-type plants [76]. Researchers identified tolerant genotypes that are proved to be more productive under extreme field stress conditions. The thermostability of the membrane has been successfully employed to evaluate HS tolerance in several crops worldwide.

\subsubsection{Photosynthesis and Respiration}

Due to ongoing climate change, it has been reported that severe climatic conditions with long light exposure and HT have increased dramatically. It is already proven that, for life on earth, photosynthesis is a vital process and is often restricted by various abiotic stresses like HS and high light conditions. The negative impact of HS on plant growth and crop yield were mainly caused by its negative impacts on the photosynthetic process, which is the most thermosensitive aspects of plant functions [77]. The relative water content (RWC), chlorophyll content, and PSII activity decreased under high light and heat co-stresses [78]. It has been found that the PSII reaction center is the vital site where damage is incurred by several abiotic stresses in the photosynthesis systems of plants [79]. It is found that photosystem II is thought to be more highly responsive to HS or high light than photosystem I [80]. The photosynthetic process is very sensitive under HS conditions, and reduction in chlorophyll contents might be one of the main reasons for the decline in photosynthesis, as an enzyme chlorophyllase helps in conversion of chlorophyll into phytol and chlorophyllide [81]. Photosynthetic acclimatization to various climatic conditions represents a modification in photosynthesis and structures at each level $[80,82]$ (Figure 3). In thylakoids, the proton gradient and non-photochemical quenching (NPQ) are the vital photo-defense process in photosystem I and photosystem II, respectively [83]. In plants, climatic stress generally results in a decrease in chlorophyll concentrations and a reduction of the 
photochemical reaction of thylakoid proteins [84-86]. It is reported that temperature is significantly affecting the photosynthetic activity of crops and photosynthetic pathways ( $\mathrm{C} 3$ or $\mathrm{C} 4$ plants). In general, for cold season $\mathrm{C} 3$ crops, the temperature range for photosynthesis is between $0{ }^{\circ} \mathrm{C}$ to $30^{\circ} \mathrm{C}$, whereas the warm-adapted $\mathrm{C} 4$ plants that are grown in summer are photo-synthetically active between $7{ }^{\circ} \mathrm{C}$ to $40{ }^{\circ} \mathrm{C}$ temperature [22,81].

In plant species (C3), at current levels of $\mathrm{CO}_{2}$ and light saturation, during the process of photo-phosphorylation, the photosynthetic response of plants to temperatures is measured by the availability of inorganic phosphates at a lower temperature, and it depends on the activity of Rubisco to fix atmospheric carbon in the optimum range of temperature. In plant species (C4) that are grown in a hot climate, the availability of Rubisco limits photosynthetic activity under low temperature, whereas at higher temperature in the thermal optimum level, it is unclear which mechanisms affect photosynthetic activity [87]. Photosynthetic rates decrease sharply as temperature increases past the optimum level [41]. This decreased rate of photosynthesis is related with declined light harvesting in photosystem II that results from cyclic electron flow [88], limitations in Rubisco, and thylakoid membrane instability [89]. In the process of photosynthesis, photoinhibition of PSII occur seven lower ranges of thermal stress [79]. However, some researchers reported slight or no harm to photosystem II due to moderate thermal stress [88].

HS decreases the rate of Photosystem II repair by the production of ROS across the thylakoid membrane [90], which is subject to influence by HS [91]. It has been found that the stability of the thylakoid membrane under $\mathrm{HS}$, situated between $32-45^{\circ} \mathrm{C}$, is mainly determined by the stability of the double bonds of fatty acids of the membrane. Fatty acids double bonds decline due to excess generation of ROS under HS circumstances and increasing membrane electron leakage, thereby enhancing the denaturation of thylakoid membrane proteins [66]. It is described that maintenance respiration (turn-over of proteins complex) is high under HS, resulting in declining availability of assimilates for crop growth and development [92]. In maize, the increase in temperature from $18-33^{\circ} \mathrm{C}$ raises the rates of maintenance respiration by greater than $80 \%$ [93]. Under elevated temperatures, the rate of respiration measurement could be an appropriate pointer for stimulation of plant response to HS, as the rate of respiration rises much more than the rate of photosynthesis initially decreases [25].

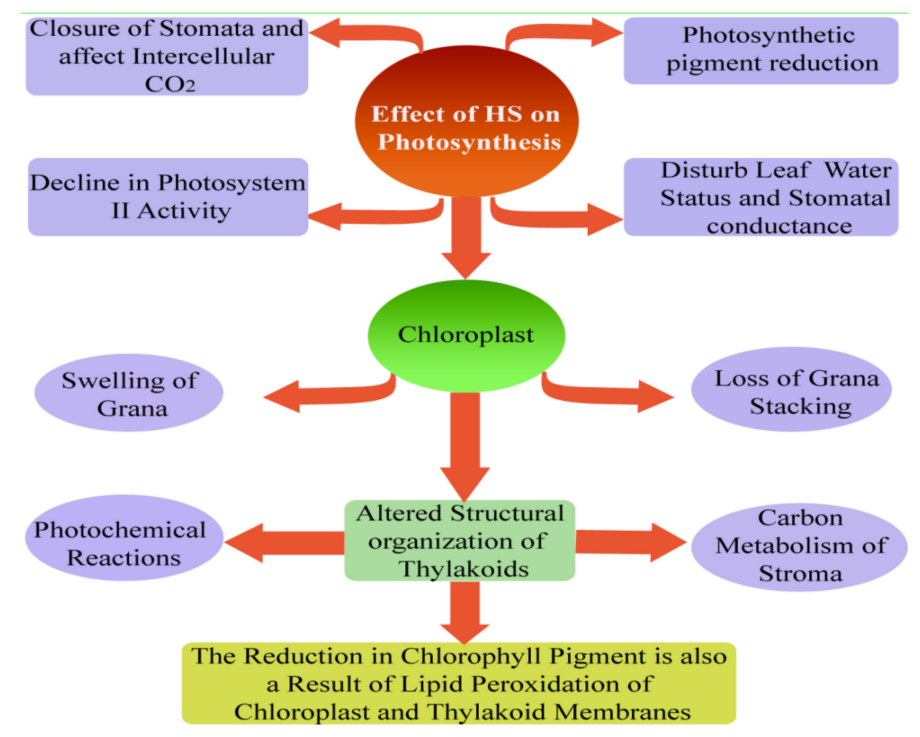

Figure 3. Decline in photosynthesis rate under heat stress. Heat stress leads to generation of reactive oxygen species, cell organelle and membrane damage, thylakoid membrane damage, thylakoid membrane lipid composition, swelling of grana, oxidative damage of cell organelle, and stomatal and non-stomatal limitations. 


\subsubsection{Water Relations}

HS has the widest and most far-reaching effects on water relations leading to a severe decrease in yield potential in various crops. HS is often linked with rapid water loss from the surface of the plant, resulting in dehydration and ultimately leading to death [94]. The increase in transpiration and movement of water is an important tool for survival of the plant under extreme temperatures $[8,95]$. It is reported that HS influences plant-water relations due to the more rapid depletion of water from the soil, which affects the temperature of soil and transpiration [96]. HS directly and indirectly affects plant functions and leads to osmotic adjustments through impaired photosynthesis, enhanced respiration, a decline in leaf osmotic potentials, and decreased sugar concentration level [97]. Under HS, water loss during daytime was more common because of increased transpiration than night time, causing stress in snap bean (Phaseolus vulgaris L.) [98]. Under severe HS, high stomatal conductance boosts transpirational heat dissipation in tolerant genotypes of chickpea as long as soil water is available [99]. A rapid decrease in leaf tissue water contents was noted in sugarcane on exposure to extreme temperature despite the fact that an ample quantity of water was available in the soil [64]. In tobacco, stomatal conductance decreases markedly under severe HS, aggravating injury to leaves [68].

\section{Oxidative Stress (OS)}

Oxidative stress is a complex physiological and chemical phenomenon in plants and develops as a result of access production and accumulation of reactive oxygen species (ROS) under stress conditions. It has been reported that many metabolic pathways are subjected to depend upon different enzymes that are highly responsive to different ranges of HS. Like other abiotic stresses, HS might uncouple several enzymes and different metabolic pathways, which results in the accumulation of undesirable and dangerous ROS, generally hydrogen-peroxide $\left(\mathrm{H}_{2} \mathrm{O}_{2}\right)$, hydroxyl-radical $\left({ }^{\bullet} \mathrm{OH}\right)$, superoxide-radical $\left(\mathrm{O}_{2}{ }^{\bullet-}\right)$, and singlet-oxygen $\left(\mathrm{O}_{2}\right)$, which leads to OS [100]. The main sites of ROS production are reaction centers of photosystem I and photosystem II in chloroplasts, though ROS are also produced in other organelles, mitochondria, and peroxisomes [101] (Figure 4). A leaner relationship is present among accumulated ROS and highest efficiency of photosystem II. It is reported that because of heat injury to photosystem I and photosystem II under such HS condition, less absorption of photons occurs [102]. Among the ROS, photo-oxidation reactions lead to the generation of $\mathrm{O}_{2}{ }^{\bullet-}$ (flavoprotein, redox cycling), during mitochondrial ETCs reactions, in chloroplasts through Mehler reaction and glyoxisomal photorespiration, by xanthine oxidase, and NADPH oxidase in membrane polypeptides and plasmamembrane. A reaction between $\mathrm{H}_{2} \mathrm{O}_{2}$ and $\mathrm{Fe}^{2+}$ (Fenton reaction) and reaction between $\mathrm{H}_{2} \mathrm{O}_{2}$ and $\mathrm{O}_{2}{ }^{\bullet-}$ leads to the formation of hydroxyl radicals (Haber-Weiss reaction) and decomposition of $\mathrm{O}_{3}$ in the apoplastic space region $[103,104]$. Photo-inhibition resulted in the formation of singlet oxygen and photosystem II electrons transfer reactions in chloroplast [104,105].

Due to HS, several physiological injuries occur in plants [102]. Hydroxyl radicals, which are produced during the process, can react with bio-molecules, pigments, lipids, proteins, DNA, and with all elements of the cell [104]. Protein denaturation as a result of thermal stress leads to OS through disruption of cell membrane stability and peroxidation of membrane lipids [106,107]. Photosynthetic activity of light reaction decreases under moderate HS is known to induce OS through the generation of ROS triggered by increased leakage of electrons from the membranes [108].

It is observed that the $\mathrm{HT}\left(33^{\circ} \mathrm{C}\right)$ leads to OS in wheat, which can change the properties of membranes and cause the degradation of proteins and deactivation of enzymes that decrease the viability of cells. HS in wheat provokes OS and also amplifies the peroxidation of the membrane and decreases the thermal stability of the membrane by $28 \%$ and $54 \%$, which enhances electrolytes leakage [109]. Premature leaf senescence in cotton was observed due to ROS generation by HS [54]. ROS accumulation at the outer surface of the plasma membrane due to continuous HS can cause membrane depolarization [110]. In such extreme cases, cell death can also occur because of ROS accumulation in cells [110]. ROS have a devastating impact on the metabolic processes of plants and triggered signaling behavior to activate the heat-shock responses toward the development of 
thermotolerance in crops [100]. Research into plant oxidative stress (OS) has shown huge potential for developing HS-tolerant crops.

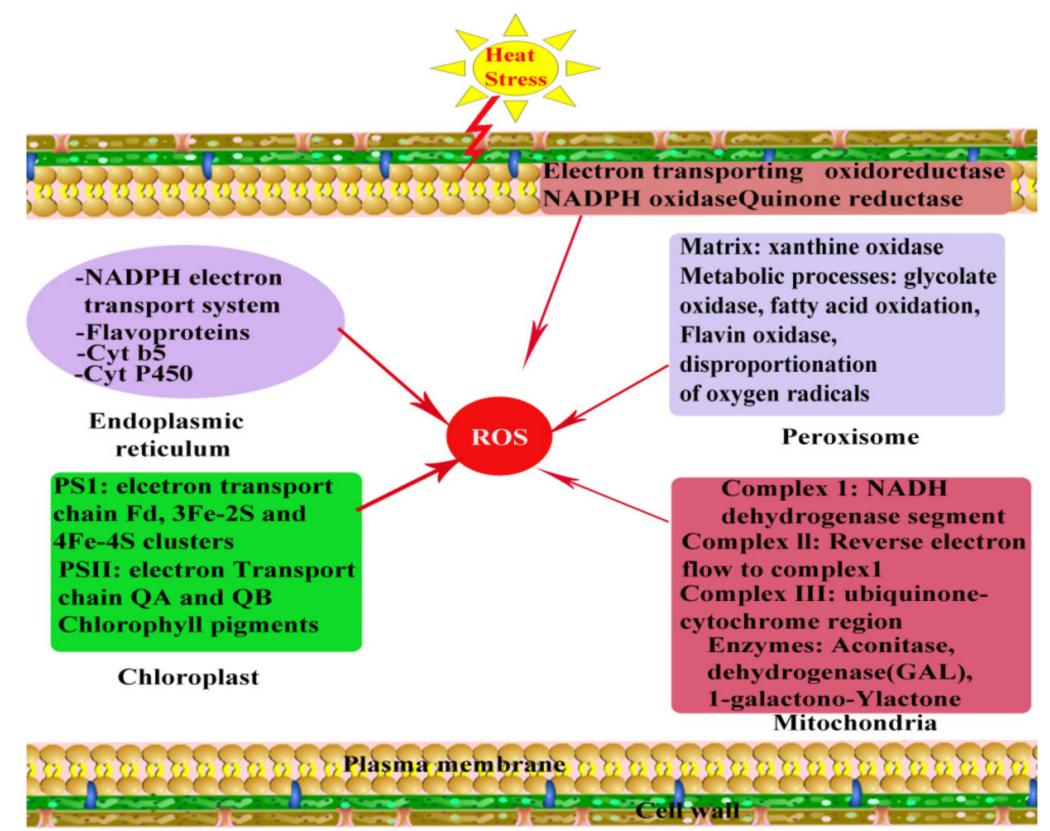

Figure 4. Reactive oxygen species (ROS) generate in plant cells as a consequence of heat stress. These reactive molecules are formed at different cellular sites, including chloroplasts, mitochondria, endoplasmic reticulum, peroxisomes, and at the extracellular side of the plasma membrane. The influence of ROS on cellular processes is mediated by both the perpetuation of their production and their amelioration by scavenging enzymes. The duration, location, and amplitude of production of ROS determine the specificity of the rapid responses under stress.

\section{Avoidance and Tolerance Mechanism}

Under HS conditions, plants show various survival mechanisms which include long-term morphological and phenological adaptations and short-term acclimation or avoidance mechanisms such as transpirational cooling, alteration of leaf orientation, or changing of membrane lipid compositions. Stomatal closure and water loss reduction, enhanced trichomatous and stomatal densities, and bigger xylem vessels are the main heat-induced features in crop plants [111]. Several plants growing in warm climatic conditions avoid HS by reducing the absorption of solar radiation. In order to avoid HS, some plants have small hairs on the leaf surface as well as cuticles (tomentose) and a waxy protective cover. The phenomenon called paraheliotropism occurs when plants often turn leaf blades away from sunlight, orient themselves parallel to solar rays, or roll their leaf blades. Under HS, early maturation is closely correlated with reduced yield losses in plants, which may be attributed to the engagement of an escape mechanism [107] (Figure 5). Such phenological and morphological adaptations are normally related with biochemical adaptations favoring net photosynthesis at HS (in particular CAM and C4 photosynthetic pathways), although C3 crop plants are also common in desert floras. HS can affect the degree of leaf rolling in many plants. The physiological role of leaf rolling is the maintenance of adaptation potential by enhancing the efficiency of water metabolism in the flag leaves of wheat under HS [112]. 


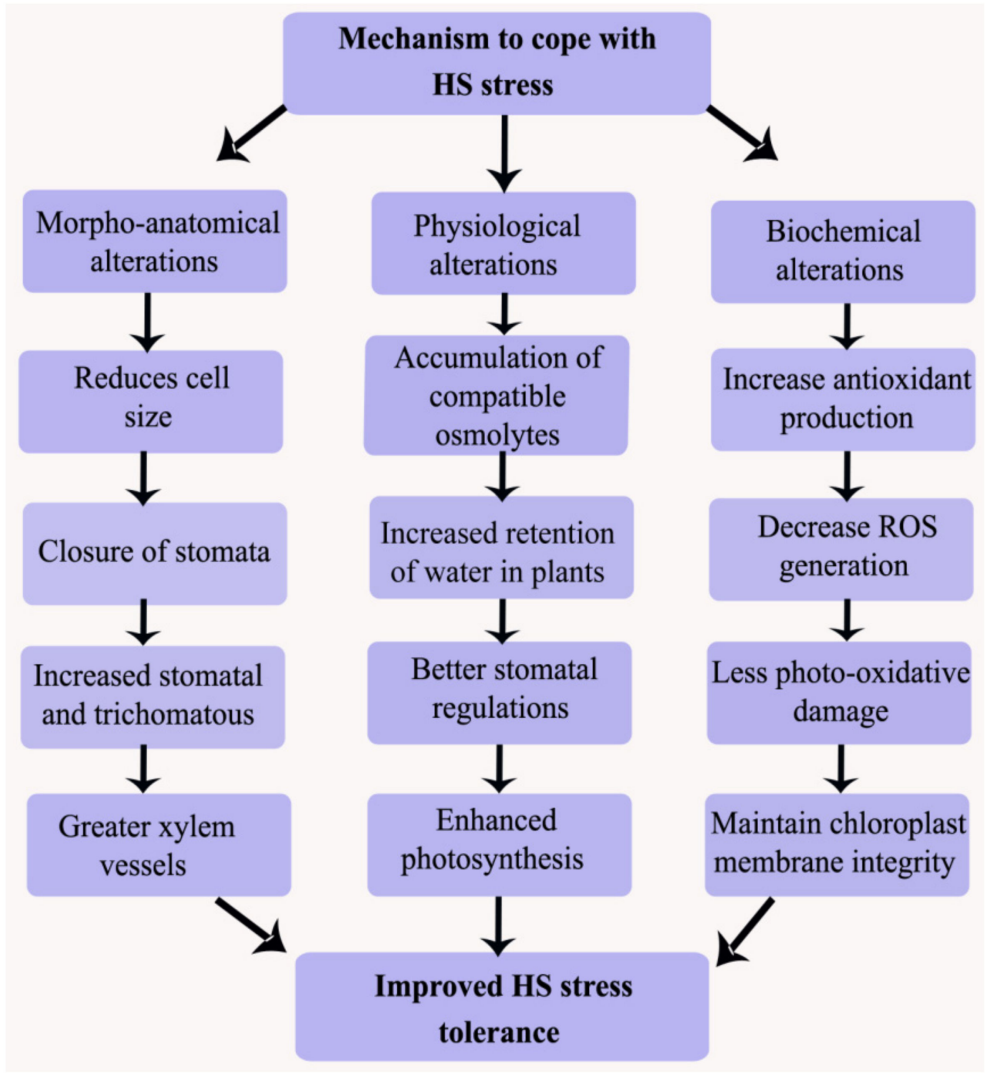

Figure 5. Flow chart of physiological, biochemical, and morphological adaptations of plants to deal with heat stress.

Thermotolerance is generally described as the capability of the plant to develop and grow to produce economic yield under HS. Plants have several survival mechanisms under HS conditions [113]. They included long-term adaptations or short-term acclimation/avoidance mechanisms. Some important mechanisms including ion transporter, late embryogenesis abundant proteins (LEA), antioxidant defense, osmoprotectants, and some factors linked with signaling cascade and transcriptional controls are fundamentally important to respond to HS [114] (Figure 5). It has been observed that several tissues in crop plants show differences in terms of developmental exposure, complexity, and responses toward the prevailing stress types [115]. These mechanisms help to regenerate homeostasis and to protect and repair damaged membranes and proteins [116].

\section{Signaling in HS Tolerance}

Signaling molecules (calcium, nitric oxide) play vital roles in conferring tolerance during HS conditions. Calcium as a divalent cation $\left(\mathrm{Ca}^{2+}\right)$ the important part of the cell membrane and cell wall and is an important intercellular messenger in the cytosol [117]. Plant roots absorbed $\mathrm{Ca}^{2+}$ from soil and are transported to shoots via xylem. The plasma membrane of a plant cell comprises $\mathrm{Ca}^{2+}$-permeable ion channels through which $\mathrm{Ca}^{2+}$ enters [118]. Higher concentrations of $\mathrm{Ca}^{2+}$ are cytotoxic, therefore, an optimum concentration is to be maintained within cells. This is done by $\mathrm{H}^{+} / \mathrm{Ca}^{2+}$ antiporters and $\mathrm{Ca}^{2+}$ ATPase $[119,120]$. The function of calcium in plants during HS has been debatable among scientists for quite some time. Some scientists doubt that the calcium chloride pretreatment leads to enhance thermotolerance and that calcium inhibitors limits plants [121,122]. Calcium and calmodulin treatment was able to induce HS transcriptional factors (HSFs) and heat shock elements (HSEs) binding in vitro, while, when treated with their inhibitors, they prevented binding at extreme HS [123]. Nitric oxide (NO) is an essential signaling molecule that controls several physiological processes and HS responses in crop plants. NO is membrane-permeable and highly 
reactive molecule that plays a vital role during critical growth and developmental stages such as germination, leaf expansion, decrease in dormancy, and plant maturation [124]. Recently, NO has gained courtesy due to its significant involvement in stress defense in several plants [8]. Application of 50 and $100 \mu \mathrm{M}$ sodium nitroprusside at $33^{\circ} \mathrm{C}$ on two wheat cultivars PBW550 (heat sensitive) and C306 (heat tolerant) showed improved activities of the antioxidative enzyme and increased heat tolerance and cellular viability [108]. In rice, pretreatment of seedlings with NO leads to less damage due to HS and enhanced rates of survival in wheat leaves and maize seedlings [125]. It is proposed that NO might be shielding plant by decreasing ROS levels, and NO was observed to activate antioxidant enzymes like APX, CAT, and SOD during HS [126]. Plants perceive internal and external signals under HS through many interlinked or independent mechanisms that are used to control several responses [127].

There are several signal transduction molecules linked to stress-responsive gene activation depending upon the type of stress and type of plant. These molecule complexes are interlinked with transcriptional factors for active stress-responsive genes. To understand the pathways and the signaling molecules involved in the development of thermotolerance, fundamental research is needed. The signaling complex mechanism under HS has been reported, which was typically found to comprise the basic bHLH (helix loop helix) transcription factors phytochromes interacting factor 4, whose ortholog has been recognized in various plant species [128].

\section{Development of HS-Tolerant Plants using Molecular and Biotechnological Approaches}

\subsection{Quantitative Trait Loci (QTLs)}

HS appears to be principally polygenic in nature, which might clarify why the genetic basis of HS tolerance in crop plants is inadequately understood $[64,129,130]$. In order to improve understanding about HS on a genetic basis, significant effort has been made to identify QTLs. Advances in DNA marker identification and genotyping assays have allowed the exact identification of the chromosomal position of the QTLs accountable for HS in crop plants [131-133]. A QTL study involving 90 introgression lines provided 5 QTLs enlightening PVs in the range of 6.83\%-14.63\% [134]. Likewise, Y106, an introgression line carrying 2 QTLs for HS tolerance (qHTS1-1 and qHTS3), was identified while transferring genes from the wild rice (O. rufipogon Griff.) [134]. Additionally, three major QTLs were mapped on chromosomes 2B, 7B, and 7D in 148 RILs (NW1014 $\times$ HUW468) are associated with HS [135].

In wheat, nine QTLs were mapped on chromosomes $(2 \mathrm{~A}, 6 \mathrm{~A}, 6 \mathrm{~B}, 3 \mathrm{~A}, 3 \mathrm{~B}$, and $7 \mathrm{~A})$ related to senescence [136]. In rice, a total of 14 QTLs related with a heat susceptibility index (HSI) were identified using parameters such as temperature depression (TD) of spike and spike yield [137]. Genome-wide association mapping as well as candidate-gene based strategies using SNP and diversity array technology (DArT) were helpful in chickpea to discover marker-trait associations for HS [138]. In tomato, six QTLs were identified for improving fruit set under HS [139]. In Brassica campestris L. ssp. Pekinensis, five QTLs related to HS has been identified [140]. In rice, a total of five QTLs (qHTS1-1, qHTS1-2, qHTS2, qHTS3, and qHTS8) were recognized on chromosomes 1, 2, 3, and 8 established on the heat response of the 90 inbred lines using 152 SSR polymorphic markers [134]. Composite interval mapping identified a total of nine HSI mapped on linkage groups 2A, 2B, and 6D in wheat [141]. Similarly, they reported that the major QTL HSI (Qhsigfd.iizwbr-2B) for grain filling duration was $28.01 \mathrm{cM}$ away from marker gwm257. Major QTLs for HSI for grain filling duration had also been described on this chromosome [135]. Other QTLs identified on to this region were more obviously linked with heat tolerance for grain filling duration [141]. Furthermore, QTLs for HSI for grain filling duration were also stated on chromosomes 1D, 2A, 6D [142], and 2D (Qlofd.iizwbr-2D) and 7A (Qlofd. iiwwr-7A) [143].

In recent studies, three major QTLs encompassing QHst.cph-3B.2, QHst.cph-3B.3, and QHst.cph-1D exposed the presence of 12 potential genes having a direct role in heat tolerance in rice [144]. Similarly, five QTLs were recognized on chromosomes 3, 5, 9, and 12 against HS. Of these QTLs, two high-effect QTLs, one novel (qSTIPSS9.1) and one known (qSTIY5.1/qSSIY5.2), were mapped in 
less than $400 \mathrm{Kbp}$ genomic regions, encompassing of 65 and 54 genes, respectively [145]. Despite the major advances in QTL mapping, there is still huge room for improvement.

\subsection{Heat Stress Proteins (HSPs) and Heat Shock Factors (HSFs)}

Heat stress proteins (HSPs) and heat shock factors (HSFs) are master players for HS tolerance in plants. Except for different biochemical and physiological mechanisms, molecular techniques are helping to understand the concept of thermotolerance in crops. HS is responsible for the up-regulation of several heat-inducible genes, commonly referred as "heat shock genes" (HSGs), which encode HSPs, and these products play important functions under stress conditions. These HSPs protect cells from the harmful impact of HS [146]. Proteomic analysis revealed that HS could down-regulate proteins playing roles in photosynthesis, energy, and metabolism and up-regulating the resistance-related proteins [147]. These proteins are grouped into five classes in plants, according to their molecular weight: Hsp100, Hsp90, Hsp70, Hsp60, and small heat-shock proteins (sHSPs) [148] (Table 2). Successful transcription, translation and post-translational modification lead to produce functional HSPs to protect the plant cell and responsible for HS tolerance [8] (Figure 6). Tolerance against HS has been accomplished in plant species transferred with heat shock regulatory proteins.

HSPs with molecular weights of 100-104 kDa are categorized into the HSP100 family. In plants, HSP100 proteins are extensively studied for their functions in HS tolerance in plants $[115,149,150]$. Among the various Arabidopsis HSP100 proteins, the cytosolic form is important for HS tolerance but not normal growth [149]. HSP90 is the most abundant in the cytosolic HSP family in both prokaryotic and eukaryotic cells and is rapidly induced in response to HS conditions. Under physiological conditions, HSP90 interconnect with several other intracellular proteins, including calmodulin, actin, tubulin, kinases, and receptor proteins [151-153]. HSP90 has been reported as a key regulator of normal growth and development in Arabidopsis and Nicotiana benthamiana L. [154-157]. Recently, over-expression of five Hsp90 genes of Glycine max in Arabidopsis resulted in reduction in lipid peroxidation and loss of chlorophyll, higher biomass production and pod setting under HS [158]. 
Table 2. Demonstration of basic role of major heat shock proteins in plants under heat stress.

\begin{tabular}{|c|c|c|c|c|c|}
\hline HSPs Major Classes & MW (KDa) & Subcellular Localization & Proposed Response & Exampled Plants & References \\
\hline Small HSP or HSP20 & $15-30$ & $\begin{array}{l}\text { Cytosol, ER, } \\
\text { mitochondria, chloroplast }\end{array}$ & $\begin{array}{l}\text { Require for the development of chloroplasts during HS, avoiding aggregation, co-chaperone, } \\
\text { and formation of high weight molecular complex (oligo-meric), which act as a matrix for stabilization of } \\
\text { unfolded protein. HSP40, HSP70 and HSP100 are required for its release. }\end{array}$ & $\begin{array}{l}\text { Arabidopsis, Rice, } \\
\text { Soybean, Wheat }\end{array}$ & [159-162] \\
\hline HSP60 & $57-69$ & Cytoplasm, mitochondria & $\begin{array}{l}\text { Specialized folding machinery, which depends upon ATP, role in embryo, and seedling development in } \\
\text { some plants, function as a chaperon in the post-translational assembly of multi-meric proteins. }\end{array}$ & $\begin{array}{l}\text { Arabidopsis, Maize, } \\
\text { bentgrass, Barley, Rye, } \\
\text { Wheat, Creeping grass }\end{array}$ & {$[113,163,164]$} \\
\hline HSP70 & 68-75 & $\begin{array}{l}\text { Cytosol, ER, nucleus, } \\
\text { mitochondria, chloroplast }\end{array}$ & $\begin{array}{l}\text { Assisting refolding and proteolytic degradation of abnormal proteins, preventing aggregation, } \\
\text { primary stabilization of proteins, metabolic detoxification, ATP dependent release and binding. }\end{array}$ & $\begin{array}{c}\text { Arabidopsis, Rice, } \\
\text { Brachypodium distachyon L., } \\
\text { Tobacco, Soybean, Citrus }\end{array}$ & {$[159,165-173]$} \\
\hline HSP90 & $82-90$ & $\begin{array}{l}\text { Cytosol, ER, nucleus, } \\
\text { mitochondria, chloroplast }\end{array}$ & $\begin{array}{l}\text { Co-regulation of thermal stress associated with signal transduction and accomplishes protein folding. } \\
\text { Genetic buffering, metabolic detoxification, regulation of receptors, protein translocation. } \\
\text { ATP is required for its function. }\end{array}$ & $\begin{array}{c}\text { Arabidopsis, } \\
\text { Chickpea, Pigeonpea }\end{array}$ & {$[159,174-176]$} \\
\hline HSP100 & 100-104 & $\begin{array}{l}\text { Cytosol, mitochondria, } \\
\text { chloroplast }\end{array}$ & $\begin{array}{l}\text { Sustain the functional integrity of convinced major polypeptides, assisting to degrade irreversibly } \\
\text { damaged polypeptides, re-solubilizing protein aggregates via interactions with the } \\
\text { SHSP chaperone system; ATP is required for its function. }\end{array}$ & Rice, Maize, Arabidopsis & {$[150,151,157,159,177-182]$} \\
\hline
\end{tabular}

Note: HSPs, Heat shock proteins; ER, Endoplasmic reticulum; sHSP, Small heat shock proteins; MW, Molecular weight. 


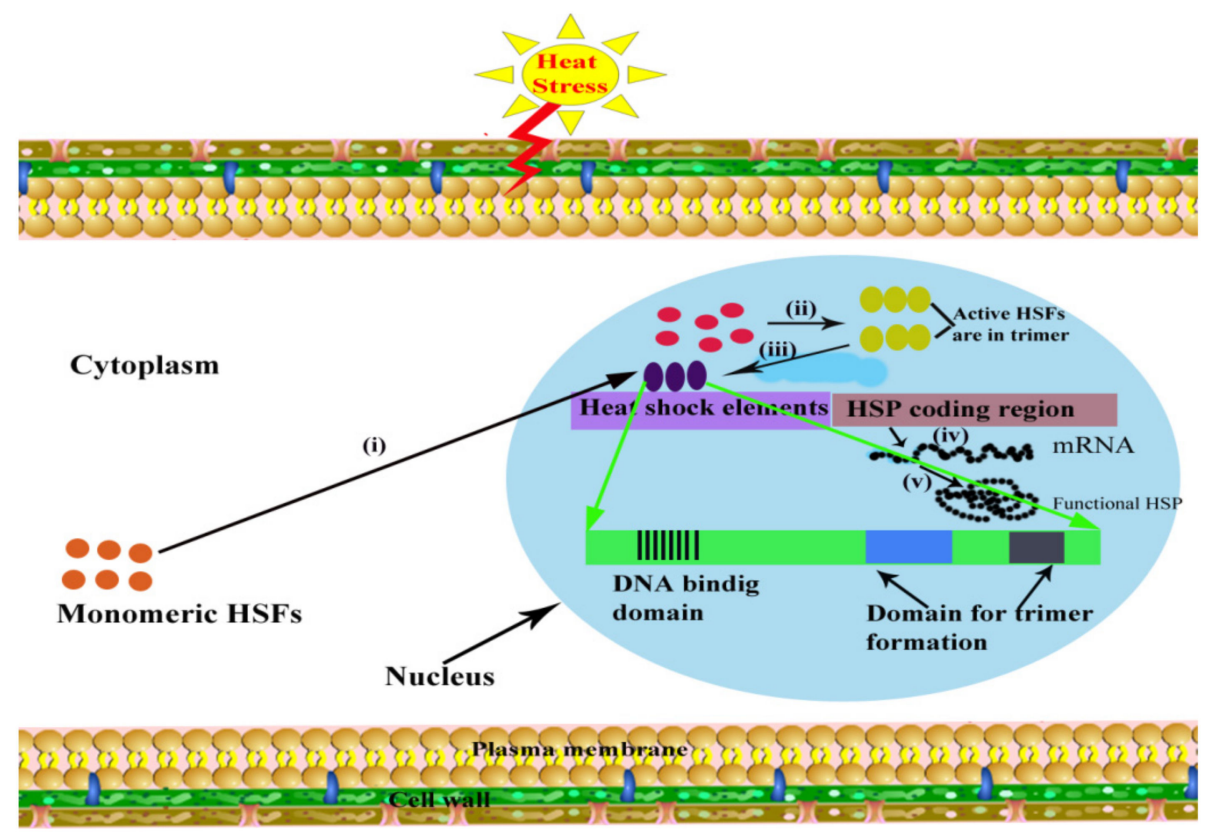

Figure 6. Illustration of the molecular regulatory mechanism of Heat Stress Proteins (HSPs) based on a hypothetical cellular model. Under heat stress, (i) monomeric Heat Shock Factors (HSFs) are entering into the nucleus from cytoplasm. (ii) HSF monomers are form active trimer in the nucleus, (iii) that will bind to the Heat Shock Element (HSE) of the respective Heat Shock Gene (HSG). Molecular dissection of the HSF binding region of HSE showing that it contains two domains for trimerization of HSFs and one DNA binding domain. (iv) Successful transcription, translation and post-translational modifications, (v) lead to produce functional HSPs (Adapted and modified from [8]).

HSP70 represents one of the most conserved classes of the heat shock proteins family. In plants and animals, HSP70 ensures proper protein folding during transfer to their final location and functions as a chaperone for newly synthesized proteins to prevent their accumulation as aggregates. HSP70 is the most highly conserved chaperones noted in plants, bacteria, and animals. These proteins associate with various other chaperones in a wide network and are implicated in diverse cellular activities [183]. Over-expression of HSP70 (HSP70-1) prevented degradation and fragmentation of nuclear DNA during HS conditions in tobacco [184]. Rice mitochondrial HSP70 over-expression resulted in the minor production of heat-induced ROS, suppressed programmed cell death, and higher mitochondrial membrane potential [184]. Chrysanthemum HSP70 expression in A. thaliana improved the tolerance against drought, salinity, and heat stresses [185].

Similar to other HSPs, sHSPs function as molecular chaperones, assisting refolding of denatured proteins and preventing undesired protein-protein interactions [151]. HSP20 or sHSPs are expressed in maximal amounts under HS conditions [160]. HSP20, a representative sHSP, maintains denatured proteins in a folding competent state and allows subsequent ATP-dependent disaggregation through the HSP70/90 chaperone system [166]. Arabidopsis plants over-expressing HSP17.5 of Nelumbo nucifera Gaertn., HSP17.8 of Rosa chinesis Jacq., HSP22 of Zea mays L., HSP26 of Saccharomyces cerevisiae, and HSP16.45 of Lilium davidii var. unicolor, showed heat tolerance to varying extents [184,186]. Tobacco plants over-expressing HSP16.9 of Z. mays resulted in increased early seed growth [184].

The research on plant HSFs regulation mainly emphasizes four levels, including transcriptional, post transcriptional, translational, and post-translation levels [187] (Figure 7). In transcription, the function of a gene can be regulated by binding of specific transcription factors (TFs) to the cis-acting elements located on the regulatory regions of its promoter [188]. Nishizawa-Yokoi et al. [188] reported that in Arabidopsis AtHSFA1d and A1e binding to the HSE in the $5^{\prime}$-flanking region of AtHSFA2 gene is involved in high light (HL)-inducible HSFA2 expression, triggering AtHSFA2 transcription. 
Dehydration-responsive element (DRE)-binding protein 2A (DREB2A gene) in the Arabidopsis directly regulates AtHSFA3 transcription via binding the two DRE core elements in the AtHSFA3 promoter under HS [189]. As AtHSFA9 is mainly expressed in late stages of seed development, a TF may be involved in the regulation of AtHSFA9 expression during the seed development stage.

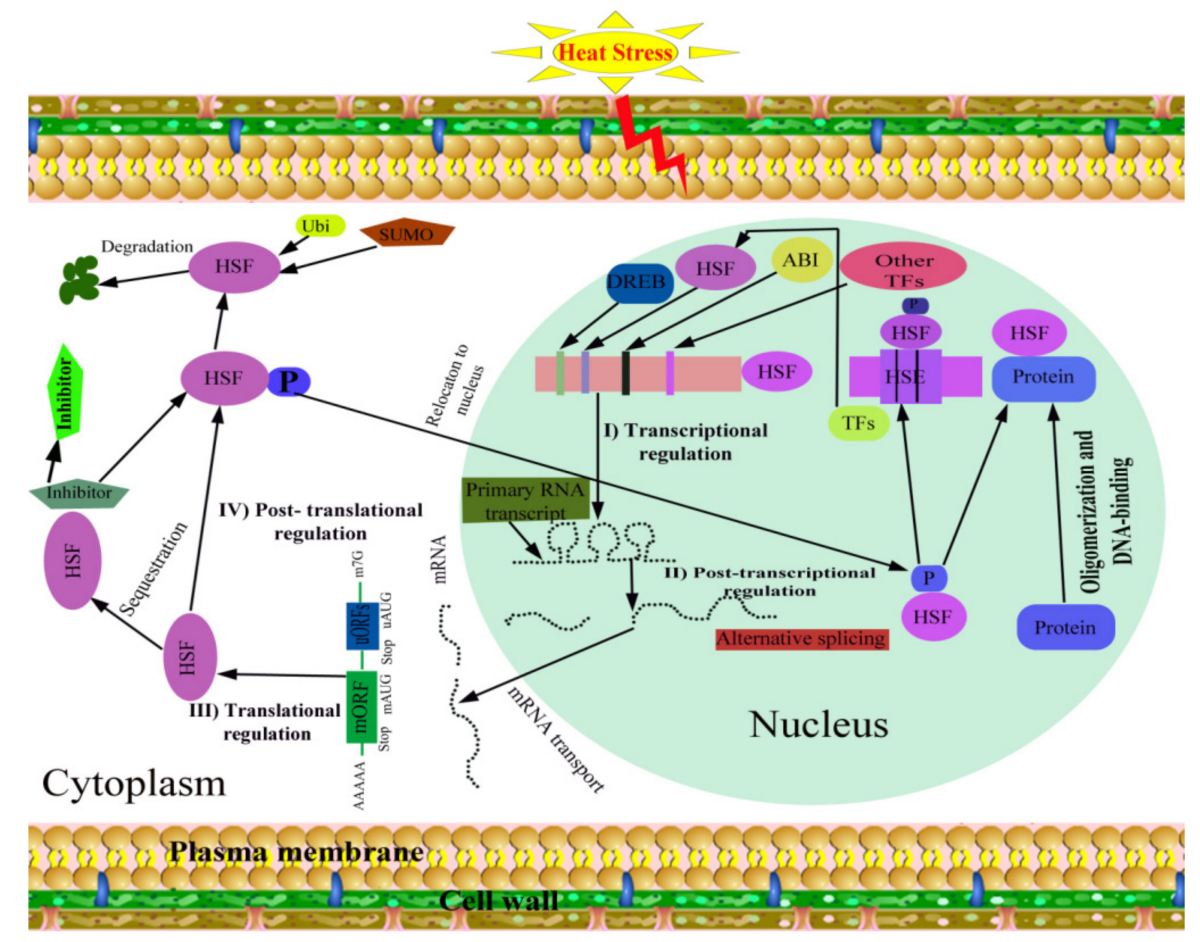

Figure 7. Illustration of the molecular regulatory mechanism of HSFs based on a hypothetical cellular model. The scheme illustrates the regulation of HSFs at (I) transcriptional, (II) post transcriptional, (III) translational, and (IV) post-translation level under heat stress. ABI, ABSCISIC ACID-INSENSITIVE protein; TFs, transcription factors; DREB, dehydration responsive element binding protein; AS, alternate splicing; m7G, cap of mRNA; mORF, major ORF; uORFs, upstream micro open reading frames; mAUG, AUG of mORF; uAUG, AUG of uORF; P, phosphate; mRNA, messenger RNA; Ubi, ubiquitination; SUMO, small ubiquitin-like modifier(Adapted and modified from [19]).

During several biological processes, HSFs post-transcriptional regulation involves alternative splicing in plants [187]. Keller et al. [190] examined HS-induced alternative splicing in the heat sensitive pollen tissue of two tomato cultivars. HS-induced alternative splicing is observed for Arabidopsis AtHSFA2, A4c, A7b, B1 and B2b [191,192]. Alternative splicing induced by HS is also observed for rice OsHSFA2d, which encodes two main splice variant proteins, OsHSFA2dI located in the nucleus and OsHSFA2dII located in the nucleus and cytoplasm, respectively [193]. These studies suggest that the HSF regulation in the plant at posttranscriptional level is diversified. It is reported that the HSF regulation in the plant at the translational level is controlled by upstream micro open reading frames (uORFs) in their $5^{\prime}$ untranslated region $[187,194,195]$. However, the investigation on uORFs of plant HSFs is generally constrained to Arabidopsis.

HSFs also go through post-translational regulation included ubiquitination, phosphorylation, oligomerization, Small Ubiquitin-like MOdifier (SUMO)-mediated degradation, and interaction with other non-HSF proteins $[196,197]$. Mitogen-activated protein kinase MAPK6 targets the AtHSFA2, phosphorylates it on T249 and alters its intracellular localization under HS in Arabidopsis [198]. AtHSFA2 was regulated by the accumulation of polyubiquitinated proteins produced by the inhibition of AtHsp9026S and proteasome [199]. It is reported that AtSUMO1 interacts with AtHSFA2 at the core SUMOylation site Lys315, leading to the repression of its transcription and ultimately disrupting the 
acquired thermotolerance in Arabidopsis [200]. Unfortunately, few active regulation factors involved in HSF regulation have been found to date.

\subsection{Development of HS-Tolerant Plants Using Genetic Engineering and Transgenic Approaches}

The devastating impacts of HS can be reduced by inducing thermotolerance in plants using different transgenic and genetic engineering techniques [107]. In addition to the investigations regarding manipulation expression of HSFs and sHSPs/chaperones, other genetically transformed plants with different degrees of thermotolerance have been developed (Table 3). Shockingly, such investigations have been relatively limited as compared to the investigations based on engineering cold, drought, or salt stress tolerance in plants. Lee et al. [201] successfully produced transgenic HS-tolerant Arabidopsis by changed HSP expression level by making a modification in the transcription factor (AtHSF1) that leads to the production of HSPs in Arabidopsis. It was reported that AtHSF1 in Arabidopsis is constitutively expressed; in optimum temperature, its activity for DNA binding, trimer-formation, and transcriptional stimulation of genes (HSPS) are suppressed. When overexpression of the gene (AtHSF1) occurs, the transcription factor is not active for thermotolerance. A fusion protein was produced as a result of a fusion between the AtHSF1 gene and $\mathrm{N}$ or $\mathrm{C}$ terminus of the gus $A$ reporter gene (for $\beta$-synthesis of glucuronidase) that was able to trimerize itself and/or with the other HSFs in the absence of heat. That fusion protein transformation into Arabidopsis created a transgenic plant that expressed HSPs constitutive and showed increased heat tolerance without requiring prior thermal treatment [8]. It has been studied that in tomato, MT-sHSP (mitochondrial small HSP) has a molecular chaperone function in vitro [202], and it has already been reported that this gene is used to produce a thermotolerantly transformed tobacco plant [203]. Researchers were able to produce transgenic thermotolerant rice after the incorporation of HSP genes. In rice, thermotolerance was developed by successful overexpression of Arabidopsis gene Hsp101 [204]. Additionally, in E. coli overexpression of Oshsp26 (sHSP) gene in rice confer enhanced tolerance to HS and other related OS [205]. The sHSP17.7 overexpression in rice plants confers thermotolerance [206].

Ono et al. [207] were able to successfully transfer a gene (Dnak1) in tobacco from the salt tolerant Cyanobacterium aphanothece halophytica and were able to successfully conferred HS tolerance. Yang et al. [208] reported that gene $(B A D H)$ transformation in the plant for the over-generation of GB osmolyte will improve thermotolerance. Heat tolerance is obtained when Rubisco activates gene transformation in tobacco for the Rubisco reversible decarboxylation; this defensive mechanism leads to safeguarding the plant photosynthetic apparatus and improvea thermotolerance [209]. The change in membrane fluidity may also alter the perception of the stress through lipid signaling, thus altering the response of defensive mechanism. Altering fatty acid composition in lipids to enhance HT stability of the photosynthetic membrane has also been shown to enhance thermotolerance and limits photo-oxidation due to the free radicals discharge. Murakami et al. [210] have been developing genetically modified $N$. tabacum L. with alteration in chloroplast membrane by silencing the gene encoding chloroplast omega-3 fatty acid desaturase. Such genetically transformed plants generate comparatively higher amounts of dienoic fatty acids and lower trienoic fatty acids in chloroplasts than the wild type. Remarkably, an NPK1-related transcript was significantly raised by heat in studies of [211]. A modest increase in thermotolerance of Arabidopsis plants constitutively expressing APX1 gene of the barley has been reported [212]. Grover et al. [184] suggested many different means to use genetically modified plant in developing thermotolerance that may be attained by overexpressing genes (HSPs) or by changing level of HSFs that control expression of non-heat shock and heat shock genes by overexpressing of other trans-acting factors like bZIP28, WRKY, and DREB2A proteins. 
Table 3. Transgenic crops, transgenes, source, and their responsible function for developing heat tolerance.

\begin{tabular}{|c|c|c|c|c|}
\hline Transgenic Crop & Gene Transferred & Source & Function & Reference \\
\hline \multirow{3}{*}{ Wheat } & TaMYB & Arabidopsis & Response to various abiotic stresses & [213] \\
\hline & TaFER-5B & T. aestivum $\mathrm{L}$. & Transgenic plant exhibited enhanced thermotolerance & [214] \\
\hline & $\mathrm{TaHsfC} 2 a$ & T. aestivum L. & $\begin{array}{l}\text { TaHsfC } 2 a \text { overexpressing wheat showed } \\
\text { improved thermotolerance }\end{array}$ & [216] \\
\hline \multirow{7}{*}{ Arabidopsis } & TaWRKY33 & T. aestivum L. & TaWRKY33 transgenic lines showed enhanced tolerance to HS & [217] \\
\hline & $\operatorname{TaNAC2L}$ & T. aestivum $\mathrm{L}$. & $\begin{array}{l}\text { Overexpression of } T a N A C 2 L \text { enhanced heat tolerance by } \\
\text { activating expression of heat-related genes }\end{array}$ & [218] \\
\hline & TaB2 & T. aestivum $\mathrm{L}$. & $\begin{array}{l}\text { Overexpression of TaB2 in Arabidopsis enhanced tolerance } \\
\text { to HS }\end{array}$ & [219] \\
\hline & TaGASR1 & T. aestivum $\mathrm{L}$. & $\begin{array}{c}\text { TaGASR1 overexpressing plant had improved tolerance to } \\
\text { HS and oxidative stress }\end{array}$ & [215] \\
\hline & TaLTP3 & T. aestivum L. & $\begin{array}{l}\text { TaLTP3 overexpressing plant showed higher } \\
\text { thermotolerance than control plants at the seedling stage }\end{array}$ & [220] \\
\hline & TaOEP16-2-5B & T. aestivum $\mathrm{L}$. & $\begin{array}{c}\text { Transgenic plant overexpressing theTaOEP16-2-5B gene } \\
\text { exhibited enhanced tolerance to HS }\end{array}$ & [221] \\
\hline & Ot NOS & O. tauri L. & $\begin{array}{c}\text { High accumulation of NO leading to thermotolerance and } \\
\text { osmotic stress }\end{array}$ & [222] \\
\hline \multirow{5}{*}{ Rice } & SBPase & Oryza. Sativa L. & Transgenic more tolerant to HS during seed development & [223] \\
\hline & HSP100, HSP101 & Arabidopsis & Synthesis of HSPs for heat tolerance & [208] \\
\hline & OsMYB48-1 & Oryza. sativa L. & Plays a positive role in in stress tolerance & [224] \\
\hline & OsHTAS & Oryza. sativa $\mathrm{L}$. & Plays a positive role in heat tolerance at the seedling stage & [225] \\
\hline & OsMYB55 & Oryza. sativa L. & Improved high temperature tolerance & [226] \\
\hline \multirow{2}{*}{ Tobacco } & $B A D H$ & S. oleracea $\mathrm{L}$. & $\begin{array}{l}\text { Overproduction of GB osmolytes that will increase } \\
\text { heat tolerance }\end{array}$ & [208] \\
\hline & Fad7 & $\begin{array}{l}\text { N. tabacum } \mathrm{L} \text {. } \\
\text { and O. sativa L. }\end{array}$ & $\begin{array}{c}\mathrm{H}_{2} \mathrm{O}_{2} \text { responsive MAPK kinase kinase (MAPKKK) synthesis } \\
\text { to protect against HS }\end{array}$ & [227] \\
\hline \multirow[t]{2}{*}{ Maize } & OsMYB55 & Oryza. Sativa L. & $\begin{array}{l}\text { Improved plant growth and performance under high } \\
\text { temperature and drought condition }\end{array}$ & [228] \\
\hline & HSP100, HSP101 & Arabidopsis & Synthesis of HSPs for heat tolerance & [115] \\
\hline Wild carrot & HSP 17.7 & Daucus carota $\mathrm{L}$. & HSPs synthesis & [206] \\
\hline Chili pepper & CaATG8C & Capsicum annuum $\mathrm{L}$. & Plant tolerance to environmental stresses & [229] \\
\hline Tomato & LeAN2 & - & $\begin{array}{c}\text { Conferred increased tolerance to HS by maintaining a low } \\
\text { levels of reactive oxygen species and high non-enzymatic } \\
\text { antioxidant activity }\end{array}$ & [230] \\
\hline
\end{tabular}

\subsection{Development of HS-Tolerance Plants Using Omics Approaches}

Keeping in view the importance of global warming as a potential threat, recent advances in "omics" approaches have offered new hopes and opportunities for the identification of post-translational, translational, and transcriptional mechanisms and signaling corridors that control the plants response to HS [8]. These "omics" approaches help to correlation and systematic analysis between alterations in microme, genome, proteome, metabolome, and transcriptome to the alteration in the responses of plant to HS and their application to enhance the probabilities of producing plants that are thermo-tolerant (Figure 8). In recent years, research has provided knowledge of the functions of proteins, metabolites, and several genes and molecular mechanisms involved in plant sensitivity to HS [96].

DNA is a basic unit of the entire molecular evidence related to thermotolerance in plant and comprises many different HS-responsive genes (genomics). Already, the identification of a huge number of genes with essential roles in HS responses has been done using genome-wide expression studies and genetic screens [231]. The transcriptory product like mRNA, from such genes in the genome, have made their transcriptomes (transcriptomics) and then proteomes (proteomics) when they translated into a functional protein (accountable for thermotolerance).

Many modern approaches such as RNA-sequencing have led to various deep expression investigations, ultimately unraveling various heat-responsive candidate genes in several 
crops $[36,232,233]$. Transcriptomic investigations of HS effects on rice, wheat, tomato, grape, and tobacco have been reported [36,134,234]. Research in rice has unraveled that HS-responsive genes in panicles and flag leaves were mainly involved in transcriptional regulation, transport, protein binding, and anti-oxidants and stress responses [235]. Transcriptomic changes drive the physiological response to progressive drought stress and rehydration in tomato [236]. In a recent study, comparative transcriptome analysis revealed the transcriptional alterations in heat-resistant and heat-sensitive sweet maize (Zea mays L.) varieties under HS [237]. Chen and Li [238] found that DEGs were responsible for HS and protein folding in Brachypodium distachyon. It has been found that a huge number of genes were differentially expressed in leaves and roots in response to HS and/or desiccation, but only a few genes were identified as overlapping heat/drought responsive genes that are mainly involved in RNA regulation, transport, hormonal metabolism, and other stresses [239]. The transcriptome approaches are important to understand the molecular and cellular changes occurring in response to HS.

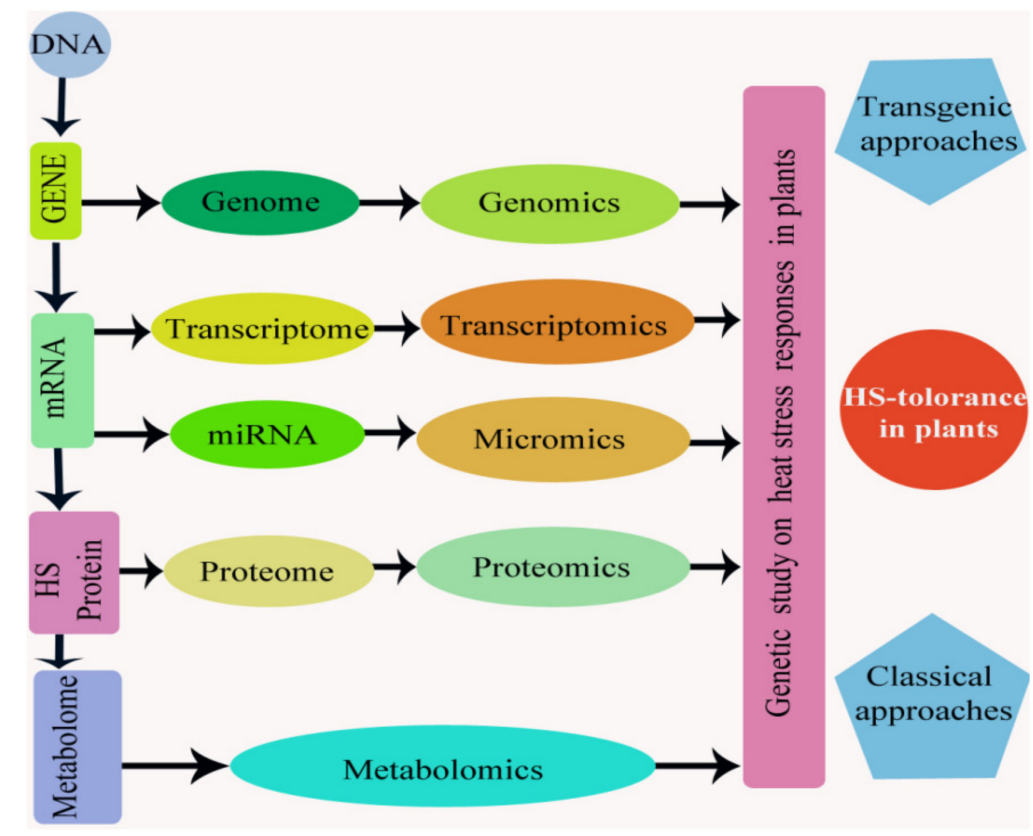

Figure 8. Illustration of integrated circuit of various "omics" techniques that correlated with each other at the molecular genetic level associated with thermotolerance in plants.

Micromics provide assistance for the better understanding of tolerance and miRNAs plays a significant role in such studies. Several thermo-tolerant responsive micro-RNAs have been recognized in plant, and their significant role in osmo-protection and nutrient deficiency response has been identified. In the onset of HS, up-regulated micro-RNAs may down-regulated their specific genes and act as negative regulators of thermotolerance, while stress down-regulated miRNAs may lead to accumulation of their target gene mRNAs, which may significantly regulate the thermotolerance. Overexpression of miRNA-resistant target genes plays an important role in plant post-transcriptional gene regulation and silencing and may result in the expression of improved traits in the genetically modified plant. Better understanding and knowledge about role of mRNAs in cellular tolerance, transcriptomehomeostasis, and the developmental and phenological plasticity of crop plants under HT and recovery will help with the genetic engineering of thermotolerance in plants.

Proteomics approaches provide important pieces of information, such as the heat-responsive proteins like HSPs and changes in proteomes under stress environments that associate to the analyses of transcriptomics and metabolomics, including the role of genes expressed in the genome's functionally translated regions linked to required traits [240]. The integration of proteomics with genetic information in legumes will give way to exciting opportunities to achieve crop improvement and 
sustainable agriculture [241]. Proteomic analysis of wheat cultivar Jing411 revealed the expression of 256 different proteins under HS [215]. Further, proteomic analysis on leaves of wheat revealed different proteins that have roles in important photosynthesis, glycolysis, stress defense, heat shock, and ATP production [85]. The proteomics analyses provide a better understanding of the molecular basis of heat-stress responses in alfalfa [62]. Additionally, proteomic analysis on soybean leaves revealed the expression of 25 different proteins that have roles in important metabolic pathways, such as RuBisCo regulation, Calvin cycle, and electron transport under high temperature [242]. In an experiment concerning the proteome analysis of roots using heat stressed root hairs and normal root hairs, 30 commonly up and down-regulated proteins were identified [243]. In an investigation, three tomato (Solanum lycopersicum L.) cultivars (LA1310 (cherry tomato), Edkawi LA 2711 (unknown heat tolerance, salt tolerant), and Walter LA3465 (heat-tolerant)) were compared for changes in leaf proteomes after HS treatment [244]. In the reproductive phase, the response of pollen to HS is mainly regulated at the proteome level, whereby proteins related to degradation and synthesis of proteins are most HS-responsive and might play a vital role in the HS-response of pollen [245]. Exogenous spermidine-induced HT resistance by proteomic approaches in tomato [246]. Lin et al. [247] utilized a physiological and proteomic approach to discover the changes in protein expression profiles of tomatoes in response to heat and flood stresses.

Moreover, in several biochemical processes, proteomes are interlinked and will manufacture deferent metabolic product under metabolomics. Metabolomics comparison between HS and major types of abiotic stresses have recognized metabolites that are commonly essential in responses to stress [248,249]. In Arabidopsis, metabolites profiling demonstrated that HS reduced the toxicity of bio-active molecules like Pro, and these events reveal that during the more severe combination of stress treatments, sucrose replaces Pro in plant as the main osmoprotectant [250]. When comparing both cold and heat response, metabolomics reveals the nature of the overlapping of major metabolites in response to HS with those metabolites that are under cold stress responses in Arabidopsis [251]. Hence, it has been found that the metabolic complex of compatible solutes (galactinol-raffinose, fructose glucose, Pro, GB etc.) have a significant role in HS tolerance. A very important protein (ATGRP7) that acts as an RNA binding protein was found that increased in response to low temperature stress and reversed when under HS. Its excess was positively correlated with concentrations of Pro and glutamine. While concentrations of galactinol and raffinose were a significant marker for heat response, their responses were independent of the response of Pro, glutamine, and ATGRP7 [248]. Such "omics" techniques are desired for the genetic molecular analyses on HS response in the plant in an integrated manner.

\subsection{Epigenetics and Heat Tolerance}

Epigenetics is defined as heritable modifications in expression and activity of a gene that occur without a change in DNA sequence and is linked with DNA methylation, histone modifications, and non-protein coding RNAs [252]. Knowledge and understanding about the Epigenetic regulation of HS responses has gained increasing interest [253,254]. A number of investigations have shown that these DNA and histone modifications play a key role in genes expression and plant development under stress conditions [255]. In Arabidopsis (Arabidopsis thaliana L.), a study investigated the malleability of the DNA methylome to stress within a generation and under repeated stress over five successive generations [256]. Arabidopsis thaliana L. imprinted gene SDC, which is silent during vegetative growth due to DNA methylation, is stimulated by heat and contributes to recovery from HS [257]. Recently, in wheat, a genome-wide survey revealed that elevated temperature had a dramatic effect on the expression of genes, but plants grown at $12{ }^{\circ} \mathrm{C}$ and $27^{\circ} \mathrm{C}$ showed slight differences in methylation pattern. However, in only a few cases was methylation associated with small changes in gene expression [254]. It is observed that DNA methylation levels were different between a thermotolerant and heat-sensitive genotype under control environments [258]. Methylation enhanced more in the heat-sensitive genotype than in the heat tolerant genotype under heat treatments. It is 
reported that more changes in the DNA methylation status of cultured microspores were observed under high temperature [259].

Histone variant deposition and histone modifications through SUMOylation and/or acetylation are considered to be involved in the HS response. Small ubiquitin-related modifier (SUMO) was recognized as a reversible post-translational modifier that contributed in the regulation of protein interactions in eukaryotes. Recent investigations have revealed that the occupancy of each histone variant of a core histone, in particular H2A and H3, play vital roles in not only genes expression but also in the assembly of chromosome centromeres and repair of DNA breaks in eukaryotes [260-262]. In Arabidopsis, it has been reported that H2A.Z deposition in gene bodies stimulates variability in the levels and gene expression patterns [261-263]. Additionally, H2A.Z plays an important role in the heat sensory response via its nucleosome occupancy. A screen of Arabidopsis (Arabidopsis thaliana L.) mutants deficient in temperature sensing under ambient temperatures $\left(12-27^{\circ} \mathrm{C}\right)$ identified actin-related protein $6(A R P 6)$ as a regulator of the coordinated alterations in gene expression in response to ambient temperature fluctuations [264]. ARP6 encodes a subunit of the SWR1 complex [265] that is necessary for inserting the alternative histone H2A.Z into nucleosomes replacing the core histone H2A, and could be involved in heat sensing [264]. In Arabidopsis, it is reported that histone acetyltransferase GENERAL CONTROL OF NONREPRESSED PROTEIN5 (GCN5) plays a vital role in HS response by facilitating H3K9 and H3K14 acetylation of HSFA3 and UV-HYPERSENSITIVE6 (UVH6) under HS [266]. The histone acetyltransferase TaGCN5 gene in wheat is upregulated under HS and that it functions similarly to GCN5 in Arabidopsis [266]. Further studies are necessary to uncover what kinds of histone modification and histone deposition contribute to the HS response in crop plants.

Recent investigations suggest that a large part of the genome is transcribed, but among transcripts, only a minor portion encodes protein. The part of transcripts that do not encode proteins are generally termed as non-protein coding RNAs (npcRNA). These npcRNAs are subdivided as regulatory npcRNAs and housekeeping npcRNAs, with the latter being further divided into long regulatory npcRNAs (greater than $300 \mathrm{bp}$ in length) and short regulatory npcRNAs (less than $300 \mathrm{bp}$ in length, such as microRNA, siRNA, piwi-RNA) [267-271]. Xin et al. [269] recognized 66 HS-responsive long npcRNAs that performed their roles in the form of long molecules. To check whether miRNAs have any functions in regulating response to HS in T. aestivum L., Xin et al. [270] cloned small RNA exposed to HS and found that 12 of the 153 miRNAs identified were responsive to HS. Kumar et al. [267] identified 37 novel miRNAs in wheat and validated six of the identified novel miRNA as HS-responsive. Interestingly, TamiR159 was down-regulated after two hours of HS treatment in T. aestivum L., but TamiR159 overexpressing Oryza sativa L. lines were more sensitive to HS relative to the wild type, showing that down-regulation of TamiR159 in T. aestivum L. after HS might participate in a HS-related signaling pathway, in turn contributing to HS tolerance [272].

\subsection{CRISPR/Cas9 Power in Genome Editing}

CRISPR/Cas9 is the most powerful gene editing tool ever seen to date. Developing more crop plants able to sustainably produce higher yield when grown under HS is an important goal if food security and crop production are to be guaranteed in the face of increasing human population and unpredictable climatic conditions. However, conventional crop improvement through random mutagenesis or genetic recombination is laborious and cannot keep pace with increasing food demands. Targeted genome editing (GE) technologies, especially CRISPR/Cas9, have great potential to produce high-yielding crops under HS. This is due to their low risk, high accuracy, and efficiency of off-target effects compared with conventional random mutagenesis approaches. [273] reviewed recent applications of the CRISPR/Cas9-mediated GE as a means to produce plants with greater resilience to the stressors they encounter when grown under harsh environments. CRISPR/Cas9-mediated GE will allow the fast development of new crop cultivars with a very low risk of off-target effects, especially 
for the crop plants that have complexity in their genomes and are not easily bred using conventional breeding approaches [274,275].

CRISPR/Cas9-mediated GE enabling the suppression or activation of target genes is also an essential tool for understanding the functioning of genes involved in plant abiotic stress resistance [276]. CRISPR/Cas9 targeted mutation of the TMS5 gene in rice cultivars led to the rapid development of temperature-sensitive lines for use in hybrid rice production [277]. Klap et al. [278] carried out CRISPR/Cas9-induced knockdown of the tomato slagamous-like 6 (SlAGL6) gene, making tomato mutant plants able to produce parthenocarpic fruits under HS. Genome editing using the CRISPR/Cas9 system can be used to modify plant genomes. However, improvements in specificity and applicability are still needed in order for the editing technique to be useful in various plant species.

\section{Conclusion and Future Prospects}

From the forgone discussion, it can be concluded that HS has significantly affected crop yield in the past several years and currently has become a key concern for crop production because it significantly affects all stages of plant growth and development. One of the reasons of the enigmatic nature of heat tolerance mechanism in plants is the dissection of a very narrow genetic pool that does not provide ample information to explore it in worldwide commercially important crop plants such wheat, cotton, maize, rice, and soybean. There is an immense need to systematically assess wild species and accessions tolerating extreme degrees of higher temperatures. In that regard, searching for novel donors with high heat tolerance or escape mechanisms is of key importance. Crop responses to HS are for the most part grouped under heat tolerance categories without having explored heat avoidance or escape phenomena, which are equally viable under field conditions. Phenotyping techniques classifying HS response into the appropriate tolerance, escape, or avoidance category is a vital first step toward developing stress-resilient crops for the future hotter climate. A complete understanding and knowledge of the nature of heat shock signaling and specific gene expression under HS will be vital for developing HS-tolerant crop plants. Despite the major advances in genetic strategies like transgenic approaches and QTL mapping, there is still huge room for improvement. For example, genetic and environmental interactions are poorly understood. However, a brief mechanism of thermotolerance remains indefinable and needs appropriate research directions. In our opinion, the genetic base for heat tolerant mechanisms in crop plants can be expanded significantly through advances in the phenotyping approaches using biochemical means including lipidomics or metabolomics which that off an impression of being promising strategies in identifying robust biochemical markers to supplement breeding efforts. Furthermore, advances in ground-based or aerial (unmanned aerial vehicles) sensor technology may also help field-based high-throughput phenotyping, which may greatly facilitate marked expansion of the genetic base incorporated into abiotic stress breeding programs. On the field scale, multiple stresses interact, and dealing with the entire complexity could be challenging, and hence addressing subcomponents (such as HS or drought stress) independently and using advanced techniques for needs based traits/genes stacking based on the target environment would be a handy mechanistic research strategy for producing crop plants that will stand out firmly in the hottest season of the year.

In the future, integration of advanced high0throughput approaches, such as microarray, genomics, and proteomics, in various developmental stages and stress conditions will provide us with transgenic plants developed for combating with HS.

Funding: This work was supported by the National Key Research and Development Program of China (2016YFD0101005), the Program of National Natural Science Foundation of China (NSFC, 31771819), the China Post-doctoral Science Foundation (2017M621990), the Natural Science for Key Project of Anhui Education Committee (KJ2016A843), and the Postdoctoral Science Foundation of Anhui province, China (2017B187).

Conflicts of Interest: The authors declare no conflicts of interest. 


$\begin{array}{ll}\text { Abbreviations } & \\ \text { APX } & \text { ascorbate peroxidase } \\ \text { Ca } & \text { calcium } \\ \text { CAT } & \text { catalase } \\ \text { GB } & \text { glycine betaine } \\ \text { HS } & \text { heat stress } \\ \text { HT } & \text { high temperature } \\ \text { HSPs } & \text { heat shock proteins } \\ \text { HSFs } & \text { heat shock transcriptional factors } \\ \text { HSEs } & \text { heat shock elements } \\ \text { LEA } & \text { late embryogenesis abundant proteins } \\ \text { MDA } & \text { malondialdehyde } \\ \text { NPQ } & \text { non-photochemical quenching } \\ \text { NO } & \text { nitric oxide } \\ \text { OS } & \text { oxidative Stress } \\ \text { PS } & \text { photosystem } \\ \text { QTLs } & \text { quantitative trait loci } \\ \text { Rubisco } & \text { ribulose-1,5-bisphosphate carboxylase/oxygenase } \\ \text { RuBP } & \text { ribulose bisphosphate } \\ \text { ROS } & \text { reactive oxygen species } \\ \text { SOD } & \text { superoxide dismutase } \\ & \end{array}$

\section{References}

1. Lobell, D.B.; Schlenker, W.; Costa-Roberts, J. Climate trends and global crop production since 1980. Science 2011, 333, 616-620. [CrossRef] [PubMed]

2. Lesk, C.; Rowhani, P.; Ramankutty, N. Influence of extreme weather disasters on global crop production. Nature 2016, 529, 84-87. [CrossRef] [PubMed]

3. Abdelrahman, M.; El-Sayed, M.; Jogaiah, S.; Burritt, D.J.; Tran, L.S.P. The "STAY-GREEN" trait and phytohormone signaling networks in plants under heat stress. Plant Cell Rep. 2017, 36, 1009-1025. [CrossRef] [PubMed]

4. Bita, C.E.; Gerats, T. Plant tolerance to high temperature in a changing environment: Scientific fundamentals and production of heat stress-tolerant crops. Front. Plant Sci. 2013, 4, 1-18. [CrossRef] [PubMed]

5. Stratonovitch, P.; Semenov, M.A. Heat tolerance around flowering in wheat identified as a key trait for increased yield potential in Europe under climate change. J. Exp. Bot. 2015, 66, 3599-3609. [CrossRef] [PubMed]

6. Lobell, D.B.; Field, C.B. Global scale climate-crop yield relationships and the impacts of recent warming. Environ. Res. Lett. 2007, 2, 14002. [CrossRef]

7. Hatfield, J.L.; Prueger, J.H. Temperature extremes: Effect on plant growth and development. Weather Clim. Extrem. 2015, 10, 4-10. [CrossRef]

8. Hasanuzzaman, M.; Nahar, K.; Alam, M.; Roychowdhury, R. Physiological, biochemical, and molecular mechanisms of heat stress tolerance in plants. Int. J. Mol. Sci. 2013, 14, 9643-9684. [CrossRef] [PubMed]

9. Das, S.; Krishnan, P.; Nayak, M.; Ramakrishnan, B. High temperature stress effects on pollens of rice (Oryza sativa L.) genotypes. Environ. Exp. Bot. 2014, 101, 36-46. [CrossRef]

10. Valliyodan, B.; Nguyen, H.T. Understanding regulatory networks and engineering for enhanced drought tolerance in plants. Curr. Opin. Plant Biol. 2006, 9, 189-195. [CrossRef] [PubMed]

11. Janská, A.; Maršík, P.; Zelenková, S.; Ovesná, J. Cold stress and acclimation-What is important for metabolic adjustment? Plant Biol. 2010, 12, 395-405. [CrossRef] [PubMed]

12. Shinozaki, K.; Yamaguchi-Shinozaki, K. Gene networks involved in drought stress response and tolerance. J. Exp. Bot. 2007, 58, 221-227. [CrossRef] [PubMed]

13. Moreno, A. A.; Orellana, A. The physiological role of the unfolded protein response in plants. Biol. Res. 2011, 44, 75-80. [CrossRef] [PubMed] 
14. Zhang, Y.; Mian, M.A.R.; Bouton, J.H. Recent molecular and genomic studies on stress tolerance of forage and turf grasses. Crop Sci. 2006, 46, 497-511. [CrossRef]

15. Koevoets, I.T.; Venema, J.H.; Elzenga, J.T.M.; Testerink, C. Roots withstanding their environment: Exploiting root system architecture responses to abiotic stress to improve crop tolerance. Front. Plant Sci. 2016, 7, 1-19. [CrossRef]

16. Fahad, S.; Bajwa, A.A.; Nazir, U.; Anjum, S.A.; Farooq, A. Crop production under drought and heat stress: Plant responses and management options. Front. Plant Sci. 2017, 8, 1-16. [CrossRef] [PubMed]

17. Gururani, M.A.; Venkatesh, J.; Tran, L.S.P. Regulation of photosynthesis during abiotic stress-induced photoinhibition. Mol. Plant 2015, 8, 1304-1320. [CrossRef] [PubMed]

18. Feller, U. Drought stress and carbon assimilation in a warming climate: Reversible and irreversible impacts. J. Plant Physiol. 2016, 203, 84-94. [CrossRef] [PubMed]

19. Guo, M.; Liu, J.-H.; Ma, X.; Luo, D.-X.; Gong, Z.-H.; Lu, M.-H. The plant heat stress transcription factors (HSFs): Structure, regulation, and function in response to abiotic stresses. Front. Plant Sci. 2016, 7. [CrossRef] [PubMed]

20. Crawford, A.J.; McLachlan, D.H.; Hetherington, A.M.; Franklin, K.A. High temperature exposure increases plant cooling capacity. Curr. Biol. 2012, 22, R396-R397. [CrossRef] [PubMed]

21. Zhao, J.; Hartmann, H.; Trumbore, S.; Ziegler, W.; Zhang, Y. High temperature causes negative whole-plant carbon balance under mild drought. New Phytol. 2013, 200, 330-339. [CrossRef] [PubMed]

22. Sage, R.F.; Zhu, X.G. Exploiting the engine of C 4 photosynthesis. J. Exp. Bot. 2011, 62, 2989-3000. [CrossRef] [PubMed]

23. Atkin, O.K.; Tjoelker, M.G. Thermal acclimation and the dynamic response of plant respiration to temperature. Trends Plant Sci. 2003, 8, 343-351. [CrossRef]

24. Wolkovich, E.M.; Cook, B.I.; Allen, J.M.; Crimmins, T.M.; Betancourt, J.L.; Travers, S.E.; Pau, S.; Regetz, J.; Davies, T.J.; Kraft, N.J.B.; et al. Warming experiments underpredict plant phenological responses to climate change. Nature 2012, 485, 494-497. [CrossRef] [PubMed]

25. Criddle, R.S.; Smith, B.N.; Hansen, L.D. A respiration based description of plant growth rate responses to temperature. Planta 1997, 201, 441-445. [CrossRef]

26. Sánchez, B.; Rasmussen, A.; Porter, J.R. Temperatures and the growth and development of maize and rice: A review. Glob. Chang. Biol. 2014, 20, 408-417. [CrossRef] [PubMed]

27. Ciais, P.; Reichstein, M.; Viovy, N.; Granier, A.; Ogée, J.; Allard, V.; Aubinet, M.; Buchmann, N.; Bernhofer, C.; Carrara, A.; et al. Europe-wide reduction in primary productivity caused by the heat and drought in 2003. Nature 2005, 437, 529-533. [CrossRef] [PubMed]

28. Morecroft, M.D.; Stokes, V.J.; Taylor, M.E.; Morison, J.I.L. Effects of climate and management history on the distribution and growth of sycamore (Acer pseudoplatanus L.) in a southern British woodland in comparison to native competitors. Forestry 2008, 81, 59-74. [CrossRef]

29. Cleland, E.E.; Chuine, I.; Menzel, A.; Mooney, H.A.; Schwartz, M.D. Shifting plant phenology in response to global change. Trends Ecol. Evol. 2007, 22, 357-365. [CrossRef] [PubMed]

30. Chmielewski, F.M.; Müller, A.; Bruns, E. Climate changes and trends in phenology of fruit trees and field crops in Germany, 1961-2000. Agric. For. Meteorol. 2004, 121, 69-78. [CrossRef]

31. Siebert, S.; Ewert, F. Future crop production threatened by extreme heat. Environ. Res. Lett. 2014, 9, 41001. [CrossRef]

32. Orbović, V.; Poff, K.L. Effect of temperature on growth and phototropism of Arabidopsis thaliana seedlings. J. Plant Growth Regul. 2007, 26, 222-228. [CrossRef]

33. Van Der Ploeg, A.; Heuvelink, E. Influence of sub-optimal temperature on tomato growth and yield: A review. J. Hortic. Sci. Biotechnol. 2005, 80, 652-659. [CrossRef]

34. Yang, L.Y.; Yang, S.L.; Li, J.Y.; Ma, J.H.; Pang, T.; Zou, C.M.; He, B.; Gong, M. Effects of different growth temperatures on growth, development, and plastid pigments metabolism of tobacco (Nicotiana tabacum L.) plants. Bot. Stud. 2018, 59. [CrossRef] [PubMed]

35. Tashiro, T.; Wardlaw, I. The response to high temperature shock and humidity changes prior to and during the early stages of grain development in wheat. Aust. J. Plant Physiol. 1990, 17, 551. [CrossRef]

36. Chao, L.M.; Liu, Y.Q.; Chen, D.Y.; Xue, X.Y.; Mao, Y.B.; Chen, X.Y. Arabidopsis transcription factors SPL1 and SPL12 confer plant thermotolerance at reproductive stage. Mol. Plant 2017, 10, 735-748. [CrossRef] [PubMed] 
37. Ferris, R.; Ellis, R.H.; Wheeler, T.R.; Hadley, P. Effect of high temperature stress at anthesis on grain yield and biomass of field-grown crops of wheat. Ann. Bot. 1998, 82, 631-639. [CrossRef]

38. Perrotta, C.; Treglia, A.S.; Mita, G.; Giangrande, E.; Rampino, P.; Ronga, G.; Spano, G.; Marmiroli, N. Analysis of mRNAs from ripening wheat seeds: The effect of high temperature. J. Cereal Sci. 1998, 27, 127-132. [CrossRef]

39. Tahir, I.S.A.; Nakata, N. Remobilization of nitrogen and carbohydrate from stems of bread wheat in response to heat stress during grain filling. J. Agron. Crop Sci. 2005, 191, 106-115. [CrossRef]

40. Dias, A.S.; Lidon, F.C. Evaluation of grain filling rate and duration in bread and durum wheat, under heat stress after anthesis. J. Agron. Crop Sci. 2009, 195, 137-147. [CrossRef]

41. Barnabás, B.; Jäger, K.; Fehér, A. The effect of drought and heat stress on reproductive processes in cereals. Plant Cell Environ. 2008, 31, 11-38. [CrossRef] [PubMed]

42. Marcelis, L.F.M. Sink strength as a determinant of dry matter partitioning in the whole plant. J. Exp. Bot. 1996, 47, 1281-1291. [CrossRef] [PubMed]

43. Boyer, J.S.; Westgate, M.E. Grain yields with limited water. J. Exp. Bot. 2004, 55, 2385-2394. [CrossRef] [PubMed]

44. Eyshi, E.; Webber, H.; Gaiser, T.; Naab, J.; Ewert, F. Heat stress in cereals: Mechanisms and modelling. Eur. J. Agron. 2015, 64, 98-113. [CrossRef]

45. Zhao, C.; Liu, B.; Piao, S.; Wang, X.; Lobell, D.B.; Huang, Y.; Huang, M.; Yao, Y.; Bassu, S.; Ciais, P.; et al. Temperature increase reduces global yields of major crops in four independent estimates. Proc. Natl. Acad. Sci. USA 2017, 114, 9326-9331. [CrossRef] [PubMed]

46. Liu, B.; Asseng, S.; Müller, C.; Ewert, F.; Elliott, J.; Lobell, D.B.; Martre, P.; Ruane, A.C.; Wallach, D.; Jones, J.W.; et al. Similar estimates of temperature impacts on global wheat yield by three independent methods. Nat. Clim. Chang. 2016, 6, 1130-1136. [CrossRef]

47. Asseng, S.; Foster, I.; Turner, N.C. The impact of temperature variability on wheat yields. Glob. Chang. Biol. 2011, 17, 997-1012. [CrossRef]

48. Lobell, D.B.; Gourdji, S.M. The influence of climate change on global crop productivity. Plant Physiol. 2012, 160, 1686-1697. [CrossRef] [PubMed]

49. Balla, K.; Rakszegi, M.; Li, Z.; Békés, F.; Bencze, S.; Veisz, O. Quality of winter wheat in relation to heat and drought shock after anthesis. Czech J. Food Sci. 2011, 29, 117-128. [CrossRef]

50. Bassu, S.; Brisson, N.; Durand, J.L.; Boote, K.; Lizaso, J.; Jones, J.W.; Rosenzweig, C.; Ruane, A.C.; Adam, M.; Baron, C.; et al. How do various maize crop models vary in their responses to climate change factors? Glob. Chang. Biol. 2014, 20, 2301-2320. [CrossRef] [PubMed]

51. Cao, Y.Y.; Duan, H.; Yang, L.N.; Wang, Z.Q.; Liu, L.J.; Yang, J.C. Effect of high temperature during heading and early filling on grain yield and physiological characteristics in indica rice. Acta Agron. Sin. 2009, 35, 512-521. [CrossRef]

52. Schlenker, W.; Roberts, M.J. Nonlinear temperature effects indicate severe damages to U.S. crop yields under climate change. Proc. Natl. Acad. Sci. USA 2009, 106, 15594-15598. [CrossRef] [PubMed]

53. Angadi, S.V.; Cutforth, H.W.; Miller, P.R.; Mcconkey, B.G.; Entz, M.H.; Brandt, S.A. Response of three Brassica species to high temperature stress during reproductive growth. Can. J. Plant Sci. 2000, 80, 693-702. [CrossRef]

54. Young, L.W.; Wilen, R.W.; Bonham-Smith, P.C. High temperature stress of Brassica napus during flowering reduces micro- and megagametophyte fertility, induces fruit abortion, and disrupts seed production. J. Exp. Bot. 2004, 55, 485-495. [CrossRef] [PubMed]

55. Cooper, P.; Rao, K.P.C.; Singh, P.; Dimes, J.; Traore, P.S.; Rao, K.; Dixit, P.; Twomlow, S.J. Farming with current and future climate risk: Advancing a "Hypothesis of Hope" for rainfed agriculture in the semi-arid tropics. J. SAT Agric. Res. 2009, 7, 1-19.

56. Tack, J.; Lingenfelser, J.; Jagadish, S.V.K. Disaggregating sorghum yield reductions under warming scenarios exposes narrow genetic diversity in US breeding programs. Proc. Natl. Acad. Sci. USA 2017, 114, 9296-9301. [CrossRef] [PubMed]

57. Debaeke, P.; Casadebaig, P.; Flenet, F.; Langlade, N. Sunflower crop and climate change: Vulnerability, adaptation, and mitigation potential from case-studies in Europe. OCL 2017, 24, D102. [CrossRef]

58. Lobell, D.B.; Bänziger, M.; Magorokosho, C.; Vivek, B. Nonlinear heat effects on African maize as evidenced by historical yield trials. Nat. Clim. Chang. 2011, 1, 42-45. [CrossRef] 
59. Lobell, D.B.; Hammer, G.L.; McLean, G.; Messina, C.; Roberts, M.J.; Schlenker, W. The critical role of extreme heat for maize production in the United States. Nat. Clim. Chang. 2013, 3, 497-501. [CrossRef]

60. Kucharik, C.J.; Serbin, S.P. Impacts of recent climate change on Wisconsin corn and soybean yield trends. Environ. Res. Lett. 2008, 3, 34003. [CrossRef]

61. Ding, X.; Jiang, Y.; He, L.; Zhou, Q.; Yu, J.; Hui, D.; Huang, D. Exogenous glutathione improves high root-zone temperature tolerance by modulating photosynthesis, antioxidant and osmolytes systems in cucumber seedlings. Sci. Rep. 2016, 6, 35424. [CrossRef] [PubMed]

62. Li, H.; Ahammed, G.J.; Zhou, G.; Xia, X.; Zhou, J.; Shi, K.; Yu, J.; Zhou, Y. Unraveling main limiting sites of photosynthesis under below- and above-ground heat stress in cucumber and the alleviatory role of luffa rootstock. Front. Plant Sci. 2016, 7, 746. [CrossRef] [PubMed]

63. Wise, R.R.; Olson, A.J.; Schrader, S.M.; Sharkey, T.D. Electron transport is the functional limitation of photosynthesis in field-grown Pima cotton plants at high temperature. Plant Cell Environ. 2004, 27, 717-724. [CrossRef]

64. Wahid, A.; Gelani, S.; Ashraf, M.; Foolad, M.R. Heat tolerance in plants: An overview. Environ. Exp. Bot. 2007, 61, 199-223. [CrossRef]

65. Salvucci, M.E.; Crafts-Brandner, S.J. Inhibition of photosynthesis by heat stress: The activation state of Rubisco as a limiting factor in photosynthesis. Physiol. Plant. 2004, 120, 179-186. [CrossRef] [PubMed]

66. Xu, S.; Li, J.; Zhang, X.; Wei, H.; Cui, L. Effects of heat acclimation pretreatment on changes of membrane lipid peroxidation, antioxidant metabolites, and ultrastructure of chloroplasts in two cool-season turfgrass species under heat stress. Environ. Exp. Bot. 2006, 56, 274-285. [CrossRef]

67. ElBasyoni, I.; Saadalla, M.; Baenziger, S.; Bockelman, H.; Morsy, S. Cell membrane stability and association mapping for drought and heat tolerance in a worldwide wheat collection. Sustainability 2017, 9, 1606. [CrossRef]

68. Tan, W.; Meng, Q.W.; Brestic, M.; Olsovska, K.; Yang, X. Photosynthesis is improved by exogenous calcium in heat-stressed tobacco plants. J. Plant Physiol. 2011, 168, 2063-2071. [CrossRef] [PubMed]

69. Lin, C.Y.; Roberts, J.K.; Key, J.L. Acquisition of thermotolerance in soybean seedlings: Synthesis and accumulation of heat shock proteins and their cellular localization. Plant Physiol. 1984, 74, 152-160. [CrossRef] [PubMed]

70. Kumar, S.; Thakur, P.; Kaushal, N.; Malik, J.A.; Gaur, P.; Nayyar, H. Effect of varying high temperatures during reproductive growth on reproductive function, oxidative stress and seed yield in chickpea genotypes differing in heat sensitivity. Arch. Agron. Soil Sci. 2013, 59, 823-843. [CrossRef]

71. Pastore, A.; Martin, S.R.; Politou, A.; Kondapalli, K.C.; Stemmler, T.; Temussi, P.A. Unbiased cold denaturation: Low- and high-temperature unfolding of yeast frataxin under physiological conditions. J. Am. Chem. Soc. 2007, 129, 5374-5375. [CrossRef] [PubMed]

72. Yamada, K.; Fukao, Y.; Hayashi, M.; Fukazawa, M.; Suzuki, I.; Nishimura, M. Cytosolic HSP90 regulates the heat shock response that is responsible for heat acclimation in Arabidopsis thaliana. J. Biol. Chem. 2007, 282, 37794-37804. [CrossRef] [PubMed]

73. Von Koskull-Döring, P.; Scharf, K.D.; Nover, L. The diversity of plant heat stress transcription factors. Trends Plant Sci. 2007, 12, 452-457. [CrossRef] [PubMed]

74. Gupta, N.K.; Agarwal, S.; Agarwal, V.P.; Nathawat, N.S.; Gupta, S.; Singh, G. Effect of short-term heat stress on growth, physiology and antioxidative defence system in wheat seedlings. Acta Physiol. Plant. 2013, 35, 1837-1842. [CrossRef]

75. Wang, L.C.; Tsai, M.C.; Chang, K.Y.; Fan, Y.S.; Yeh, C.H.; Wu, S.J. Involvement of the Arabidopsis HIT1/AtVPS53 tethering protein homologue in the acclimation of the plasma membrane to heat stress. J. Exp. Bot. 2011, 62, 3609-3620. [CrossRef] [PubMed]

76. Xu, Q.; Xu, X.; Shi, Y.; Xu, J.; Huang, B. Transgenic tobacco plants overexpressing a grass PpEXP1 gene exhibit enhanced tolerance to heat stress. PLoS ONE 2014, 9, e100792. [CrossRef] [PubMed]

77. Wang, D.; Heckathorn, S.A.; Mainali, K.; Tripathee, R. Timing effects of heat-stress on plant ecophysiological characteristics and growth. Front. Plant Sci. 2016, 7, 1-11. [CrossRef] [PubMed]

78. Chen, Y.; Zhang, Z.; Tao, F.; Palosuo, T.; Rötter, R.P. Impacts of heat stress on leaf area index and growth duration of winter wheat in the North China Plain. Field Crop. Res. 2017, 230-237. [CrossRef]

79. Murata, N.; Takahashi, S.; Nishiyama, Y.; Allakhverdiev, S.I. Photoinhibition of photosystem II under environmental stress. Biochim. Biophys. Acta-Bioenerg. 2007, 1767, 414-421. [CrossRef] [PubMed] 
80. Zivcak, M.; Brestic, M.; Kalaji, H.M.; Govindjee. Photosynthetic responses of sun- and shade-grown barley leaves to high light: Is the lower PSII connectivity in shade leaves associated with protection against excess of light? Photosynth. Res. 2014, 119, 339-354. [CrossRef] [PubMed]

81. Mishra, D.; Shekhar, S.; Agrawal, L.; Chakraborty, S.; Chakraborty, N. Cultivar-specific high temperature stress responses in bread wheat (triticum aestivum L.) associated with physicochemical traits and defense pathways. Food Chem. 2017, 221, 1077-1087. [CrossRef] [PubMed]

82. Brestic, M.; Zivcak, M.; Olsovska, K.; Shao, H.-B.; Kalaji, H.M.; Allakhverdiev, S.I. Reduced glutamine synthetase activity plays a role in control of photosynthetic responses to high light in barley leaves. Plant Physiol. Biochem. 2014, 81, 74-83. [CrossRef] [PubMed]

83. Brestic, M.; Zivcak, M.; Kunderlikova, K.; Sytar, O.; Shao, H.; Kalaji, H.M.; Allakhverdiev, S.I. Low PSI content limits the photoprotection of PSI and PSII in early growth stages of chlorophyll b-deficient wheat mutant lines. Photosynth. Res. 2015, 125, 151-166. [CrossRef] [PubMed]

84. Su, X.; Wu, S.; Yang, L.; Xue, R.; Li, H.; Wang, Y.; Zhao, H. Exogenous progesterone alleviates heat and high light stress-induced inactivation of photosystem II in wheat by enhancing antioxidant defense and D1 protein stability. Plant Growth Regul. 2014, 74, 311-318. [CrossRef]

85. Wang, X.; Dinler, B.S.; Vignjevic, M.; Jacobsen, S.; Wollenweber, B. Physiological and proteome studies of responses to heat stress during grain filling in contrasting wheat cultivars. Plant Sci. 2015, 230, 33-50. [CrossRef] [PubMed]

86. Chen, Y.-E.; Liu, W.-J.; Su, Y.-Q.; Cui, J.-M.; Zhang, Z.-W.; Yuan, M.; Zhang, H.-Y.; Yuan, S. Different response of photosystem II to short and long-term drought stress in Arabidopsis thaliana. Physiol. Plant. 2016, 158, 225-235. [CrossRef] [PubMed]

87. Sage, R.F.; Kubien, D.S. The temperature response of C3 and C4 photosynthesis. Plant Cell Environ. 2007, 30, 1086-1106. [CrossRef] [PubMed]

88. Sharkey, T.D. Effects of moderate heat stress on photosynthesis: Importance of thylakoid reactions, rubisco deactivation, reactive oxygen species, and thermotolerance provided by isoprene. Plant Cell Environ. 2005, 28, 269-277. [CrossRef]

89. Crafts-Brandner, S.J.; Salvucci, M.E. Sensitivity of photosynthesis heat stress in a C4 plant, maize, to heat stress. Plant Physiol. 2002, 129, 1773-1780. [CrossRef] [PubMed]

90. Takahashi, S.; Murata, N. Interruption of the Calvin cycle inhibits the repair of Photosystem II from photodamage. Biochim. Biophys. Acta-Bioenerg. 2005, 1708, 352-361. [CrossRef] [PubMed]

91. Bukhov, N.G.; Wiese, C.; Neimanis, S.; Heber, U. Heat sensitivity of chloroplasts and leaves: Leakage of protons from thylakoids and reversible activation of cyclic electron transport. Photosynth. Res. 1999, 59, 81-93. [CrossRef]

92. Peng, S.; Huang, J.; Sheehy, J.E.; Laza, R.C.; Visperas, R.M.; Zhong, X.; Centeno, G.S.; Khush, G.S.; Cassman, K.G. Rice yields decline with higher night temperature from global warming. Proc. Natl. Acad. Sci. USA 2004, 101, 9971-9975. [CrossRef] [PubMed]

93. Penning De Vries, F.W.T. The cost of maintenance processes in plant cells. Ann. Bot. 1975, 39, 77-92. [CrossRef]

94. Koini, M.A.; Alvey, L.; Allen, T.; Tilley, C.A.; Harberd, N.P.; Whitelam, G.C.; Franklin, K.A. High temperature-mediated adaptations in plant architecture require the bHLH transcription factor PIF4. Curr. Biol. 2009, 19, 408-413. [CrossRef] [PubMed]

95. Kolb, P.F.; Robberecht, R. High temperature and drought stress effects on survival of Pinus ponderosa seedlings. Tree Physiol. 1996, 16, 665-672. [CrossRef] [PubMed]

96. Sita, K.; Sehgal, A.; HanumanthaRao, B.; Nair, R.M.; Vara Prasad, P.V.; Kumar, S.; Gaur, P.M.; Farroq, M.; Siddique, K.H.M.; Varshney, R.K.; et al. Food legumes and rising temperatures: Effects, adaptive functional mechanisms specific to reproductive growth stage and strategies to improve heat tolerance. Front. Plant Sci. 2017, 8, 1-30. [CrossRef] [PubMed]

97. Prasad, P.V.V.; Staggenborg, S.A.; Ristic, Z.; Ahuja, L.R.; Reddy, V.R.; Saseendran, S.A.; Yu, Q. Impacts of drought and/or heat stress on physiological, developmental, growth, and yield processes of crop plants. In Response of Crops to Limited Water: Understanding and Modeling Water Stress Effects on Plant Growth Processes; American Society of Agronomy; Crop Science Society of America; Soil Science Society of America: Madison, WI, USA, 2008; ISBN 978-0-89118-188-0. 
98. Tsukaguchi, T.; Kawamitsu, Y.; Takeda, H.; Suzuki, K.; Egawa, Y. Water status of flower buds and leaves as affected by high temperature in heat-tolerant and heat-sensitive cultivars of snap bean (Phaseolus vulgaris L.). Plant Prod. Sci. 2003, 6, 24-27. [CrossRef]

99. Kaushal, N.; Awasthi, R.; Gupta, K.; Gaur, P.; Siddique, K.H.M.; Nayyar, H. Heat-stress-induced reproductive failures in chickpea (Cicer arietinum) are associated with impaired sucrose metabolism in leaves and anthers. Funct. Plant Biol. 2013, 40, 1334-1349. [CrossRef]

100. Asada, K. Production and scavenging of reactive oxygen species in chloroplasts and their functions. Plant Physiol. 2006, 141, 391-396. [CrossRef] [PubMed]

101. Soliman, W.S.; Fujimori, M.; Tase, K.; Sugiyama, S.-I. Oxidative stress and physiological damage under prolonged heat stress in C3 grass Lolium perenne. Grassl. Sci. 2011, 57, 101-106. [CrossRef]

102. Halliwell, B. Oxidative stress and neurodegeneration: Where are we now? J. Neurochem. 2006, 97, 1634-1658. [CrossRef] [PubMed]

103. Møller, I.M.; Jensen, P.E.; Hansson, A. Oxidative Modifications to Cellular Components in Plants. Annu. Rev. Plant Biol. 2007, 58, 459-481. [CrossRef] [PubMed]

104. Karuppanapandian, T.; Wang, H.W.; Prabakaran, N.; Jeyalakshmi, K.; Kwon, M.; Manoharan, K.; Kim, W. 2,4-dichlorophenoxyacetic acid-induced leaf senescence in mung bean (Vigna radiata L. Wilczek) and senescence inhibition by co-treatment with silver nanoparticles. Plant Physiol. Biochem. 2011, 49, 168-177. [CrossRef] [PubMed]

105. Huang, B.; Xu, C. Identification and characterization of proteins associated with plant tolerance to heat stress. J. Integr. Plant Biol. 2008, 50, 1230-1237. [CrossRef] [PubMed]

106. Camejo, D.; Jiménez, A.; Alarcón, J.J.; Torres, W.; Gómez, J.M.; Sevilla, F. Changes in photosynthetic parameters and antioxidant activities following heat-shock treatment in tomato plants. Funct. Plant Biol. 2006, 33, 177-187. [CrossRef]

107. Rodríguez, M.; Canales, E.; Borrás-hidalgo, O. Molecular aspects of abiotic stress in plants. Biotecnol. Apl. 2005, 22, 1-10. [CrossRef]

108. Bavita, A.; Shashi, B.; Navtej, S.B. Nitric oxide alleviates oxidative damage induced by high temperature stress in wheat. CSIR-NISCAIR 2012, 50, 372-378.

109. Savicka, M.; Škute, N. Effects of high temperature on malondialdehyde content, superoxide production and growth changes in wheat seedlings (Triticum aestivum L.). Ekologija 2010, 56, 26-33. [CrossRef]

110. Qi, Y.; Wang, H.; Zou, Y.; Liu, C.; Liu, Y.; Wang, Y.; Zhang, W. Over-expression of mitochondrial heat shock protein 70 suppresses programmed cell death in rice. FEBS Lett. 2011, 585, 231-239. [CrossRef] [PubMed]

111. Srivastava, S.; Pathak, A.D.; Gupta, P.S.; Kumar, A.; Kumar, A. Hydrogen peroxide-scavenging enzymes impart tolerance to high temperature induced oxidative stress in sugarcane. J. Environ. Biol. 2012, 33, 657-661. [PubMed]

112. Sarieva, G.E.; Kenzhebaeva, S.S.; Lichtenthaler, H.K. Adaptation potential of photosynthesis in wheat cultivars with a capability of leaf rolling under high temperature conditions. Russ. J. Plant Physiol. 2010, 57, 28-36. [CrossRef]

113. Wang, W.; Vinocur, B.; Shoseyov, O.; Altman, A. Role of plant heat-shock proteins and molecular chaperones in the abiotic stress response. Trends Plant Sci. 2004, 9, 244-252. [CrossRef] [PubMed]

114. Sehgal, A.; Sita, K.; Nayyar, H. Heat stress in plants: Sensing and defense mechanisms. J. plant Sci. Res. 2016, 32, 195-210.

115. Queitsch, C. Heat shock protein 101 plays a crucial role in thermotolerance in Arabidopsis. Plant Cell Online 2000, 12, 479-492. [CrossRef]

116. Vinocur, B.; Altman, A. Recent advances in engineering plant tolerance to abiotic stress: Achievements and limitations. Curr. Opin. Biotechnol. 2005, 16, 123-132. [CrossRef] [PubMed]

117. White, P.J.; Broadley, M.R. Calcium in plants. Ann. Bot. 2003, 92, 487-511. [CrossRef] [PubMed]

118. White, P.J. Calcium channels in higher plants. Biochim. Biophys. Acta-Biomembr. 2000, 1465, $171-189$. [CrossRef]

119. Hirschi, K. Vacuolar $\mathrm{H}^{+} / \mathrm{Ca}^{2+}$ transport: Who's directing the traffic? Trends Plant Sci. 2001, 6, 100-104. [CrossRef]

120. Sze, H.; Liang, F.; Hwang, I.; Curran, A.C.; Harper, J.F. Diversity and regulation of plant Ca ${ }^{2+}$ p umps: Insights from Expression in Yeast. Annu. Rev. Plant Physiol. Plant Mol. Biol. 2002, 51, 433-462. [CrossRef] [PubMed] 
121. Larkindale, J.; Knight, M.R. Protection against heat stress-induced oxidative damage in arabidopsis involves calcium, abscisic acid, ethylene, and salicylic acid. Plant Physiol. 2002, 128, 682-695. [CrossRef] [PubMed]

122. Larkindale, J.; Huang, B. Thermotolerance and antioxidant systems in Agrostis stolonifera: Involvement of salicylic acid, abscisic acid, calcium, hydrogen peroxide, and ethylene. J. Plant Physiol. 2004, 161, 405-413. [CrossRef] [PubMed]

123. Li, B.; Liu, H.; Sun, D.; Zhou, R. $\mathrm{Ca}^{2+}$ and calmodulin modulate DNA-binding activity of maize heat shock transcription factor in vitro. Plant Cell Physiol. 2004, 45, 627-634. [CrossRef] [PubMed]

124. Mishina, T.E.; Zeier, J. Pathogen-associated molecular pattern recognition rather than development of tissue necrosis contributes to bacterial induction of systemic acquired resistance in Arabidopsis. Plant J. 2007, 50, 500-513. [CrossRef] [PubMed]

125. Uchida, A.; Jagendorf, A.T.; Hibino, T.; Takabe, T.; Takabe, T. Effects of hydrogen peroxide and nitric oxide on both salt and heat stress tolerance in rice. Plant Sci. 2002, 163, 515-523. [CrossRef]

126. Song, L.; Ding, W.; Zhao, M.; Sun, B.; Zhang, L. Nitric oxide protects against oxidative stress under heat stress in the calluses from two ecotypes of reed. Plant Sci. 2006, 171, 449-458. [CrossRef] [PubMed]

127. Kaur, N.; Gupta, A.K. Signal transduction pathways under abiotic stresses in plants. Curr. Sci. 2005, 88, 1771-1780.

128. Proveniers, M.C.G.; Van Zanten, M. High temperature acclimation through PIF4 signaling. Trends Plant Sci. 2013, 18, 59-64. [CrossRef] [PubMed]

129. Collins, N.C.; Tardieu, F.; Tuberosa, R. Quantitative trait loci and crop performance under abiotic stress: Where do we stand? Plant Physiol. 2008, 147, 469-486. [CrossRef] [PubMed]

130. Ainsworth, E.A.; Ort, D.R. How do we improve crop production in a warming world? Plant Physiol. 2010, 154, 526-530. [CrossRef] [PubMed]

131. Jagadish, S.V.K.; Muthurajan, R.; Oane, R.; Wheeler, T.R.; Heuer, S.; Bennett, J.; Craufurd, P.Q. Physiological and proteomic approaches to address heat tolerance during anthesis in rice (Oryza sativa L.). J. Exp. Bot. 2010, 61, 143-156. [CrossRef] [PubMed]

132. Pinto, R.S.; Reynolds, M.P.; Mathews, K.L.; McIntyre, C.L.; Olivares-Villegas, J.J.; Chapman, S.C. Heat and drought adaptive QTL in a wheat population designed to minimize confounding agronomic effects. Theor. Appl. Genet. 2010, 121, 1001-1021. [CrossRef] [PubMed]

133. Bonneau, J.; Taylor, J.; Parent, B.; Bennett, D.; Reynolds, M.; Feuillet, C.; Langridge, P.; Mather, D. Multi-environment analysis and improved mapping of a yield-related QTL on chromosome 3B of wheat. Theor. Appl. Genet. 2013, 126, 747-761. [CrossRef] [PubMed]

134. Lei, D.; Tan, L.; Liu, F.; Chen, L.; Sun, C. Identification of heat-sensitive QTL derived from common wild rice (Oryza rufipogon Griff.). Plant Sci. 2013, 201, 121-127. [CrossRef] [PubMed]

135. Paliwal, R.; Röder, M.S.; Kumar, U.; Srivastava, J.P.; Joshi, A.K. QTL mapping of terminal heat tolerance in hexaploid wheat (T. aestivum L.). Theor. Appl. Genet. 2012, 125, 561-575. [CrossRef] [PubMed]

136. Vijayalakshmi, K.; Fritz, A.K.; Paulsen, G.M.; Bai, G.; Pandravada, S.; Gill, B.S. Modeling and mapping QTL for senescence-related traits in winter wheat under high temperature. Mol. Breed. 2010, 26, 163-175. [CrossRef]

137. Mason, R.E.; Mondal, S.; Beecher, F.W.; Hays, D.B. Genetic loci linking improved heat tolerance in wheat (Triticum aestivum L.) to lower leaf and spike temperatures under controlled conditions. Euphytica 2011, 180, 181-194. [CrossRef]

138. Thudi, M.; Upadhyaya, H.D.; Rathore, A.; Gaur, P.M.; Krishnamurthy, L.; Roorkiwal, M.; Nayak, S.N.; Chaturvedi, S.K.; Basu, P.S.; Gangarao, N.V.P. R.; et al. Genetic dissection of drought and heat tolerance in chickpea through genome-wide and candidate gene-based association mapping approaches. PLoS ONE 2014, 9, e96758. [CrossRef] [PubMed]

139. Grilli, G.V.G.; Braz, L.T.; Lemos, E.G.M. QTL identification for tolerance to fruit set in tomato by FAFLP markers. Crop Breed. Appl. Biotechnol. 2007, 7, 234-241. [CrossRef]

140. Shuancang, Y.; Yongiian, W.; Xiaoying, Z. Mapping and analysis QTL controlling heat tolerance in Brassica campestris L. ssp pekinensis. Acta Hortic. Sin. 2003, 30, 417-420.

141. Bhusal, N.; Sarial, A.K.; Sharma, P.; Sareen, S. Mapping QTLs for grain yield components in wheat under heat stress. PLoS ONE 2017, 12, e0189594. [CrossRef] [PubMed] 
142. Mason, R.E.; Mondal, S.; Beecher, F.W.; Pacheco, A.; Jampala, B.; Ibrahim, A.M.H.; Hays, D.B. QTL associated with heat susceptibility index in wheat (Triticum aestivum L.) under short-term reproductive stage heat stress. Euphytica 2010, 174, 423-436. [CrossRef]

143. Tiwari, C.; Wallwork, H.; Kumar, U.; Dhari, R.; Arun, B.; Mishra, V.K.; Reynolds, M.P.; Joshi, A.K. Molecular mapping of high temperature tolerance in bread wheat adapted to the Eastern Gangetic Plain region of India. Field Crop. Res. 2013, 154, 201-210. [CrossRef]

144. Sharma, D.K.; Torp, A.M.; Rosenqvist, E.; Ottosen, C.O.; Andersen, S.B. QTLs and potential candidate genes for heat stress tolerance identified from the mapping populations specifically segregating for $\mathrm{F} \mathrm{v} / \mathrm{F} \mathrm{m}$ in wheat. Front. Plant Sci. 2017, 8. [CrossRef] [PubMed]

145. Ps, S.; Sv, A.M.; Prakash, C.; Mk, R.; Tiwari, R.; Mohapatra, T.; Singh, N.K. High resolution mapping of QTLs for heat tolerance in rice using a 5K SNP array. Rice 2017, 10. [CrossRef] [PubMed]

146. Chang, H.C.; Tang, Y.C.; Hayer-Hartl, M.; Hartl, F.U. SnapShot: Molecular chaperones, Part I. Cell 2007, 128, 89-90. [CrossRef] [PubMed]

147. Zhou, W.-H.; Xue, D.-W.; Zhang, G.-P. Protein response of rice leaves to high temperature stress and its difference of genotypes at different growth stage. Acta Agron. Sin. 2011, 37, 820-831. [CrossRef]

148. Al-Whaibi, M.H. Plant heat-shock proteins: A mini review. J. King Saud Univ.-Sci. 2011, 23, 139-150. [CrossRef]

149. Hong, S.W.; Vierling, E. Hsp101 is necessary for heat tolerance but dispensable for development and germination in the absence of stress. Plant J. 2001, 27, 25-35. [CrossRef] [PubMed]

150. Lin, M.Y.; Chai, K.H.; Ko, S.S.; Kuang, L.Y.; Lur, H.S.; Charng, Y.Y. A positive feedback loop between HEAT SHOCK PROTEIN101 and HEAT STRESS-ASSOCIATED 32-KD PROTEIN modulates long-term acquired thermotolerance illustrating diverse heat stress responses in rice varieties. Plant Physiol. 2014, 164, 2045-2053. [CrossRef] [PubMed]

151. Gupta, S.C.; Sharma, A.; Mishra, M.; Mishra, R.K.; Chowdhuri, D.K. Heat shock proteins in toxicology: How close and how far? Life Sci. 2010, 86, 377-384. [CrossRef] [PubMed]

152. Nguyen, N.; Francoeur, N.; Chartrand, V.; Klarskov, K.; Guillemette, G.; Boulay, G. Insulin promotes the association of heat shock protein 90 with the inositol 1,4,5-trisphosphate receptor to dampen its Ca2+ release activity. Endocrinology 2009, 150, 2190-2196. [CrossRef] [PubMed]

153. Te, J.; Jia, L.; Rogers, J.; Miller, A.; Hartson, S.D. Novel subunits of the mammalian Hsp90 signal transduction chaperone. J. Proteome Res. 2007, 6, 1963-1973. [CrossRef] [PubMed]

154. Liu, Y.; Burch-Smith, T.; Schiff, M.; Feng, S.; Dinesh-Kumar, S.P. Molecular chaperone Hsp90 associates with resistance protein $\mathrm{N}$ and its signaling proteins SGT1 and Rar1 to modulate an innate immune response in plants. J. Biol. Chem. 2004, 279, 2101-2108. [CrossRef] [PubMed]

155. Queitsch, C.; Sangstert, T.A.; Lindquist, S. Hsp90 as a capacitor of phenotypic variation. Nature 2002, 417, 618-624. [CrossRef] [PubMed]

156. Sangster, T.A.; Queitsch, C. The HSP90 chaperone complex, an emerging force in plant development and phenotypic plasticity. Curr. Opin. Plant Biol. 2005, 8, 86-92. [CrossRef] [PubMed]

157. Sangster, T.A.; Bahrami, A.; Wilczek, A.; Watanabe, E.; Schellenberg, K.; McLellan, C.; Kelley, A.; Kong, S.W.; Queitsch, C.; Lindquist, S. Phenotypic diversity and altered environmental plasticity in Arabidopsis thaliana with reduced Hsp90 levels. PLoS ONE 2007, 2. [CrossRef] [PubMed]

158. Xu, J.; Xue, C.; Xue, D.; Zhao, J.; Gai, J.; Guo, N.; Xing, H. Overexpression of GmHsp90s, a heat shock protein90 (Hsp90) gene family cloning from soybean, decrease damage of abiotic stresses in Arabidopsis thaliana. PLOS ONE 2013, 8, e69810. [CrossRef]

159. Swindell, W.R.; Huebner, M.; Weber, A.P. Transcriptional profiling of Arabidopsis heat shock proteins and transcription factors reveals extensive overlap between heat and non-heat stress response pathways. BMC Genom. 2007, 8, 125. [CrossRef] [PubMed]

160. Liberek, K.; Lewandowska, A.; Ziętkiewicz, S. Chaperones in control of protein disaggregation. EMBO J. 2008, 27, 328-335. [CrossRef] [PubMed]

161. Zhong, L.; Zhou, W.; Wang, H.; Ding, S.; Lu, Q.; Wen, X.; Peng, L.; Zhang, L.; Lu, C. Chloroplast small heat shock protein HSP21 interacts with plastid nucleoid protein pTAC5 and is essential for chloroplast development in arabidopsis under heat stress. Plant Cell 2013, 25, 2925-2943. [CrossRef] [PubMed]

162. Sarkar, N.K.; Kim, Y.K.; Grover, A. Rice sHsp genes: Genomic organization and expression profiling under stress and development. BMC Genom. 2009, 10, 393. [CrossRef] [PubMed] 
163. Itoh, H.; Komatsuda, A.; Ohtani, H.; Wakui, H.; Imai, H.; Sawada, K.I.; Otaka, M.; Ogura, M.; Suzuki, A.; Hamada, F. Mammalian HSP60 is quickly sorted into the mitochondria under conditions of dehydration. Eur. J. Biochem. 2002, 269, 5931-5938. [CrossRef] [PubMed]

164. Apuya, N.R. The Arabidopsis embryo mutant schlepperless has a defect in the Chaperonin-60alpha gene. Plant Physiol. 2001, 126, 717-730. [CrossRef] [PubMed]

165. Sung, D.; Kaplan, F.; Guy, C.L. Plant Hsp70 molecular chaperones: Protein structure, gene family, expression and function. Physiol Plant 2001, 113, 443-451. [CrossRef]

166. Su, P.H.; Li, H.M. Arabidopsis stromal 70-kD heat shock proteins are essential for plant development and important for thermotolerance of germinating seeds. Plant Physiol. 2008, 146, 1231-1241. [CrossRef] [PubMed]

167. Park, C.J.; Bart, R.; Chern, M.; Canlas, P.E.; Bai, W.; Ronald, P.C. Overexpression of the endoplasmic reticulum chaperone BiP3 regulates XA21-mediated innate immunity in rice. PLoS ONE 2010, 5. [CrossRef] [PubMed]

168. Hartl, F.U.; Bracher, A.; Hayer-Hartl, M. Molecular chaperones in protein folding and proteostasis. Nature 2011, 475, 324-332. [CrossRef] [PubMed]

169. Frydman, J. Folding of newly translated proteins in vivo: The role of molecular chaperones. Annu. Rev. Biochem. 2001, 70, 603-647. [CrossRef] [PubMed]

170. Usman, M. G.; Rafii, M. Y.; Martini, M. Y.; Yusuff, O. A.; Ismail, M. R.; Miah, G. Molecular analysis of Hsp70 mechanisms in plants and their function in response to stress. Biotechnol. Genet. Eng. Rev. 2017, 33, $26-39$. [CrossRef] [PubMed]

171. Jung, K.H.; Gho, H.J.; Nguyen, M.X.; Kim, S.R.; An, G. Genome-wide expression analysis of HSP70 family genes in rice and identification of a cytosolic HSP70 gene highly induced under heat stress. Funct. Integr. Genom. 2013, 13, 391-402. [CrossRef] [PubMed]

172. Yu, A.; Li, P.; Tang, T.; Wang, J.; Chen, Y.; Liu, L. Roles of Hsp70s in stress responses of microorganisms, plants, and animals. Biomed. Res. Int. 2015, 2015. [CrossRef] [PubMed]

173. Wen, F.; Wu, X.; Li, T.; Jia, M.; Liu, X.; Li, P.; Zhou, X.; Ji, X.; Yue, X. Genome-wide survey of heat shock factors and heat shock protein 70s and their regulatory network under abiotic stresses in Brachypodium distachyon. PLoS ONE 2017, 12, e0180352. [CrossRef] [PubMed]

174. Pratt, W.B.; Toft, D.O. Regulation of signaling protein function and trafficking by the hsp90/hsp70-based chaperone machinery. Exp. Biol. Med. 2003, 228, 111-133.

175. Bao, F.; Huang, X.; Zhu, C.; Zhang, X.; Li, X.; Yang, S. Arabidopsis HSP90 protein modulates RPP4-mediated temperature-dependent cell death and defense responses. New Phytol. 2014, 202, 1320-1334. [CrossRef] [PubMed]

176. Agarwal, G.; Garg, V.; Kudapa, H.; Doddamani, D.; Pazhamala, L.T.; Khan, A.W.; Thudi, M.; Lee, S.H.; Varshney, R.K. Genome-wide dissection of AP2/ERF and HSP90 gene families in five legumes and expression profiles in chickpea and pigeonpea. Plant Biotechnol. J. 2016, 14, 1563-1577. [CrossRef] [PubMed]

177. Zuo, D.; Subjeck, J.; Wang, X.Y. Unfolding the Role of Large Heat Shock Proteins: New Insights and Therapeutic Implications. Front. Immunol. 2016, 7, 75. [CrossRef] [PubMed]

178. Kim, N.H.; Hwang, B.K. Pepper heat shock protein 70a interacts with the Type III Effector AvrBsT and triggers plant cell death and immunity. Plant Physiol. 2015, 167, 307-322. [CrossRef] [PubMed]

179. Nieto-Sotelo, J. Maize HSP101 plays important roles in both induced and basal thermotolerance and primary root growth. Plant Cell Online 2002, 14, 1621-1633. [CrossRef]

180. Wu, T.Y.; Juan, Y.T.; Hsu, Y.H.; Wu, S.H.; Liao, H.T.; Fung, R.W.M.; Charng, Y.Y. Interplay between heat shock proteins HSP101 and HSA32 prolongs heat acclimation memory posttranscriptionally in Arabidopsis. Plant Physiol. 2013, 161, 2075-2084. [CrossRef] [PubMed]

181. Lee, U.; Rioflorido, I.; Hong, S.W.; Larkindale, J.; Waters, E.R.; Vierling, E. The Arabidopsis ClpB/Hsp100 family of proteins: Chaperones for stress and chloroplast development. Plant J. 2007, 49, 115-127. [CrossRef] [PubMed]

182. Zhou, L.; Liu, Z.; Liu, Y.; Kong, D.; Li, T.; Yu, S.; Mei, H.; Xu, X.; Liu, H.; Chen, L.; et al. A novel gene OsAHL1 improves both drought avoidance and drought tolerance in rice. Sci. Rep. 2016, 6, 1-15. [CrossRef] [PubMed]

183. Wang, Y.; Lin, S.; Song, Q.; Li, K.; Tao, H.; Huang, J.; Chen, X.; Que, S.; He, H. Genome-wide identification of heat shock proteins (Hsps) and Hsp interactors in rice: Hsp70s as a case study. BMC Genom. 2014, 15. [CrossRef] [PubMed] 
184. Grover, A.; Mittal, D.; Negi, M.; Lavania, D. Generating high temperature tolerant transgenic plants: Achievements and challenges. Plant Sci. 2013, 205-206, 38-47. [CrossRef] [PubMed]

185. Song, A.; Zhu, X.; Chen, F.; Gao, H.; Jiang, J.; Chen, S. A chrysanthemum heat shock protein confers tolerance to Abiotic stress. Int. J. Mol. Sci. 2014, 15, 5063-5078. [CrossRef] [PubMed]

186. Mu, C.; Zhang, S.; Yu, G.; Chen, N.; Li, X.; Liu, H. Overexpression of small heat shock protein LimHSP16.45 in Arabidopsis enhances tolerance to abiotic stresses. PLoS ONE 2013, 8. [CrossRef] [PubMed]

187. Fragkostefanakis, S.; Röth, S.; Schleiff, E.; Scharf, K.D. Prospects of engineering thermotolerance in crops through modulation of heat stress transcription factor and heat shock protein networks. Plant Cell Environ. 2015, 38, 1881-1895. [CrossRef] [PubMed]

188. Nishizawa-Yokoi, A.; Nosaka, R.; Hayashi, H.; Tainaka, H.; Maruta, T.; Tamoi, M.; Ikeda, M.; Ohme-Takagi, M.; Yoshimura, K.; Yabuta, Y.; et al. HsfA1d and HsfA1e involved in the transcriptional regulation of hsfa2 function as key regulators for the hsf signaling network in response to environmental stress. Plant Cell Physiol. 2011, 52, 933-945. [CrossRef] [PubMed]

189. Yoshida, T.; Sakuma, Y.; Todaka, D.; Maruyama, K.; Qin, F.; Mizoi, J.; Kidokoro, S.; Fujita, Y.; Shinozaki, K.; Yamaguchi-Shinozaki, K. Functional analysis of an Arabidopsis heat-shock transcription factor HsfA3 in the transcriptional cascade downstream of the DREB2A stress-regulatory system. Biochem. Biophys. Res. Commun. 2008, 368, 515-521. [CrossRef] [PubMed]

190. Keller, M.; Hu, Y.; Mesihovic, A.; Fragkostefanakis, S.; Schleiff, E.; Simm, S. Alternative splicing in tomato pollen in response to heat stress. DNA Res. 2017, 24, 205-217. [CrossRef] [PubMed]

191. Sugio, A.; Dreos, R.; Aparicio, F.; Maule, A.J. The cytosolic protein response as a subcomponent of the wider heat shock response in Arabidopsis. Plant Cell Online 2009, 21, 642-654. [CrossRef] [PubMed]

192. Liu, J.; Sun, N.; Liu, M.; Liu, J.; Du, B.; Wang, X.; Qi, X. An autoregulatory loop controlling Arabidopsis HsfA2 expression: Role of heat shock-induced alternative splicing. Plant Physiol. 2013, 162, 512-521. [CrossRef] [PubMed]

193. Cheng, Q.; Zhou, Y.; Liu, Z.; Zhang, L.; Song, G.; Guo, Z.; Wang, W.; Qu, X.; Zhu, Y.; Yang, D. An alternatively spliced heat shock transcription factor, OsHSFA2dI, functions in the heat stress-induced unfolded protein response in rice. Plant Biol. 2015, 17, 419-429. [CrossRef] [PubMed]

194. Jorgensen, R.A.; Dorantes-Acosta, A.E. Conserved peptide upstream open reading frames are associated with regulatory genes in angiosperms. Front. Plant Sci. 2012, 3, 191. [CrossRef] [PubMed]

195. Von Arnim, A.G.; Jia, Q.; Vaughn, J.N. Regulation of plant translation by upstream open reading frames. Plant Sci. 2014, 214, 1-12. [CrossRef] [PubMed]

196. Scharf, K.D.; Berberich, T.; Ebersberger, I.; Nover, L. The plant heat stress transcription factor (Hsf) family: Structure, function and evolution. Biochim. Biophys. Acta-Gene Regul. Mech. 2012, 1819, 104-119. [CrossRef] [PubMed]

197. Song, L.; Jiang, Y.; Zhao, H.; Hou, M. Acquired thermotolerance in plants. Plant Cell. Tissue Organ Cult. 2012, 111, 265-276. [CrossRef]

198. Evrard, A.; Kumar, M.; Lecourieux, D.; Lucks, J.; von Koskull-Döring, P.; Hirt, H. Regulation of the heat stress response in Arabidopsis by MPK6-targeted phosphorylation of the heat stress factor HsfA2. PeerJ 2013, 1, e59. [CrossRef] [PubMed]

199. Nishizawa-Yokoi, A.; Tainaka, H.; Yoshida, E.; Tamoi, M.; Yabuta, Y.; Shigeoka, S. The 26S proteasome function and Hsp90 activity involved in the regulation of HsfA2 expression in response to oxidative stress. Plant Cell Physiol. 2010, 51, 486-496. [CrossRef] [PubMed]

200. Cohen-Peer, R.; Schuster, S.; Meiri, D.; Breiman, A.; Avni, A. Sumoylation of Arabidopsis heat shock factor A2 (HsfA2) modifies its activity during acquired thermotholerance. Plant Mol. Biol. 2010, 74, 33-45. [CrossRef] [PubMed]

201. Lee, J.H.; Hübel, A.; Schöffl, F.H. Derepression of the activity of genetically engineered heat shock factor causes constitutive synthesis of heat shock proteins and increased thermotolerance in transgenic Arabidopsis. Plant J. 1995, 8, 603-612. [CrossRef] [PubMed]

202. Liu, J.; Shono, M. Characterization of mitochondria-located small heat shock protein from tomato (Lycopersicon esculentum). Plant Cell Physiol. 1999, 40, 1297-1304. [PubMed]

203. Sanmiya, K.; Suzuki, K.; Egawa, Y.; Shono, M. Mitochondrial small heat-shock protein enhances thermotolerance in tobacco plants. FEBS Lett. 2004, 557, 265-268. [CrossRef] 
204. Katiyar-Agarwal, S.; Agarwal, M.G.A. Heat-tolerant basmati rice engineered by over-expression of hsp101. Plant Mol. Biol. 2003, 677-686. [CrossRef]

205. Lee, B.H.; Won, S.H.; Lee, H.S.; Miyao, M.; Chung, W.I.; Kim, I.J.; Jo, J. Expression of the chloroplast-localized small heat shock protein by oxidative stress in rice. Gene 2000, 245, 283-290. [CrossRef]

206. Murakami, T.; Matsuba, S.; Funatsuki, H.; Kawaguchi, K.; Saruyama, H.; Tanida, M.; Sato, Y. Over-expression of a small heat shock protein, sHSP17.7, confers both heat tolerance and UV-B resistance to rice plants. Mol. Breed. 2004, 13, 165-175. [CrossRef]

207. Ono, K.; Hibino, T.; Kohinata, T.; Suzuki, S.; Tanaka, Y.; Nakamura, T.; Takabe, T.; Takabe, T. Overexpression of DnaK from a halotolerant cyanobacterium Aphanothece halophytica enhances the high-temperatue tolerance of tobacco during germination and early growth. Plant Sci. 2001, 160, 455-461. [CrossRef]

208. Yang, X.; Liang, Z.; Lu, C. Genetic engineering of the biosynthesis of glycinebetaine enhances photosynthesis against high temperature stress in transgenic tobacco plants. Plant Physiol. 2005, 138, 2299-2309. [CrossRef] [PubMed]

209. Sharkey, T.D.; Badger, M.R.; von Caemmerer, S.; Andrews, T.J. Increased heat sensitivity of photosynthesis in tobacco plants with reduced Rubisco activase. Photosynth. Res. 2001, 67, 147-156. [CrossRef] [PubMed]

210. Murakami, Y.; Tsuyama, M.; Kobayash, Y.; Kodama, H.; Iba, K. Trienoic fatty acids and plant tolerance of high temperature. Science 2000, 287, 476-479. [CrossRef] [PubMed]

211. Rizhsky, L. When Defense Pathways Collide. The response of Arabidopsis to a combination of drought and heat stress. Plant Physiol. 2004, 134, 1683-1696. [CrossRef] [PubMed]

212. Shi, W.M.; Muramoto, Y.; Ueda, A.; Takabe, T. Cloning of peroxisomal ascorbate peroxidase gene from barley and enhanced thermotolerance by overexpressing in Arabidopsis thaliana. Gene 2001, 273, 23-27. [CrossRef]

213. Zhao, Y.; Tian, X.; Wang, F.; Zhang, L.; Xin, M.; Hu, Z.; Yao, Y.; Ni, Z.; Sun, Q.; Peng, H. Characterization of wheat MYB genes responsive to high temperatures. BMC Plant Biol. 2017, 17, 208. [CrossRef] [PubMed]

214. Zang, X.; Geng, X.; Wang, F.; Liu, Z.; Zhang, L.; Zhao, Y.; Tian, X.; Ni, Z.; Yao, Y.; Xin, M.; et al. Overexpression of wheat ferritin gene TaFER-5B enhances tolerance to heat stress and other abiotic stresses associated with the ROS scavenging. BMC Plant Biol. 2017, 17, 14. [CrossRef] [PubMed]

215. Zhang, L.; Geng, X.; Zhang, H.; Zhou, C.; Zhao, A.; Wang, F.; Zhao, Y.; Tian, X.; Hu, Z.; Xin, M.; et al. Isolation and characterization of heat-responsive gene TaGASR1 from wheat (Triticum aestivum L.). J. Plant Biol. 2017, 60, 57-65. [CrossRef]

216. Hu, X.J.; Chen, D.; Lynne Mclntyre, C.; Fernanda Dreccer, M.; Zhang, Z.B.; Drenth, J.; Kalaipandian, S.; Chang, H.; Xue, G.P. Heat shock factor C2a serves as a proactive mechanism for heat protection in developing grains in wheat via an ABA-mediated regulatory pathway. Plant Cell Environ. 2017, 41, 79-98. [CrossRef] [PubMed]

217. He, G.H.; Xu, J.Y.; Wang, Y.X.; Liu, J.M.; Li, P.S.; Chen, M.; Ma, Y.Z.; Xu, Z.S. Drought-responsive WRKY transcription factor genes TaWRKY1 and TaWRKY33 from wheat confer drought and/or heat resistance in Arabidopsis. BMC Plant Biol. 2016, 16, 116. [CrossRef] [PubMed]

218. Guo, W.; Zhang, J.; Zhang, N.; Xin, M.; Peng, H.; Hu, Z.; Ni, Z.; Du, J. The wheat NAC transcription factor TaNAC2L is regulated at the transcriptional and post-translational levels and promotes heat stress tolerance in transgenic arabidopsis. PLoS ONE 2015, 10, e0135667. [CrossRef] [PubMed]

219. Singh, A.; Khurana, P. Molecular and functional characterization of a wheat B2 protein imparting adverse temperature tolerance and influencing plant growth. Front. Plant Sci. 2016, 7, 642. [CrossRef]

220. Zang, X.; Geng, X.; Liu, K.; Wang, F.; Liu, Z.; Zhang, L.; Zhao, Y.; Tian, X.; Hu, Z.; Yao, Y.; et al. Ectopic expression of TaOEP16-2-5B, a wheat plastid outer envelope protein gene, enhances heat and drought stress tolerance in transgenic Arabidopsis plants. Plant Sci. 2017, 258, 1-11. [CrossRef] [PubMed]

221. Wang, F.; Zang, X.; Kabir, M.R.; Liu, K.; Liu, Z.; Ni, Z.; Yao, Y.; Hu, Z.; Sun, Q.; Peng, H. A wheat lipid transfer protein 3 could enhance the basal thermotolerance and oxidative stress resistance of Arabidopsis. Gene 2014, 550, 18-26. [CrossRef] [PubMed]

222. Foresi, N.; Mayta, M.L.; Lodeyro, A.F.; Scuffi, D.; Correa-Aragunde, N.; García-Mata, C.; Casalongué, C.; Carrillo, N.; Lamattina, L. Expression of the tetrahydrofolate-dependent nitric oxide synthase from the green alga Ostreococcus tauri increases tolerance to abiotic stresses and influences stomatal development in Arabidopsis. Plant J. 2015, 82, 806-821. [CrossRef] [PubMed] 
223. Feng, L.; Wang, K.; Li, Y.; Tan, Y.; Kong, J.; Li, H.; Li, Y.; Zhu, Y. Overexpression of SBPase enhances photosynthesis against high temperature stress in transgenic rice plants. Plant Cell Rep. 2007, 26, 1635-1646. [CrossRef] [PubMed]

224. Xiong, H.; Li, J.; Liu, P.; Duan, J.; Zhao, Y.; Guo, X.; Li, Y.; Zhang, H.; Ali, J.; Li, Z. Overexpression of OsMYB48-1, a novel MYB-related transcription factor, enhances drought and salinity tolerance in rice. PLoS ONE 2014, 9, e92913. [CrossRef] [PubMed]

225. Liu, J.; Zhang, C.; Wei, C.; Liu, X.; Wang, M.; Yu, F.; Xie, Q.; Tu, J. The RING Finger Ubiquitin E3 Ligase OsHTAS enhances heat tolerance by promoting $\mathrm{H}_{2} \mathrm{O}_{2}$-induced stomatal closure in rice. Plant Physiol. 2016, 170, 429-443. [CrossRef] [PubMed]

226. El-kereamy, A.; Bi, Y.M.; Ranathunge, K.; Beatty, P.H.; Good, A.G.; Rothstein, S.J. The rice R2R3-MYB transcription factor OsMYB55 is involved in the tolerance to high temperature and modulates amino acid metabolism. PLOS ONE 2012, 7. [CrossRef]

227. Sohn, S.O.; Back, K. Transgenic rice tolerant to high temperature with elevated contents of dienoic fatty acids. Biol. Plant. 2007, 51, 340-342. [CrossRef]

228. Casaretto, J.A.; El-kereamy, A.; Zeng, B.; Stiegelmeyer, S.M.; Chen, X.; Bi, Y.M.; Rothstein, S.J. Expression of OsMYB55 in maize activates stress-responsive genes and enhances heat and drought tolerance. BMC Genom. 2016, 17, 312. [CrossRef] [PubMed]

229. Zhai, Y.; Wang, H.; Liang, M.; Lu, M. Both silencing- and over-expression of pepper CaATG8c gene compromise plant tolerance to heat and salt stress. Environ. Exp. Bot. 2017, 141, 10-18. [CrossRef]

230. Meng, X.; Wang, J.R.; Wang, G.D.; Liang, X.Q.; Li, X.D.; Meng, Q.W. An R2R3-MYB gene, LeAN2, positively regulated the thermo-tolerance in transgenic tomato. J. Plant Physiol. 2015, 175, 191-197. [CrossRef] [PubMed]

231. Yeh, C.H.; Kaplinsky, N.J.; Hu, C.; Charng, Y.Y. Some like it hot, some like it warm: Phenotyping to explore thermotolerance diversity. Plant Sci. 2012, 195, 10-23. [CrossRef] [PubMed]

232. Priest, H.D.; Fox, S.E.; Rowley, E.R.; Murray, J.R.; Michael, T.P.; Mockler, T.C. Analysis of global gene expression in Brachypodium distachyon reveals extensive network plasticity in response to abiotic stress. PLoS ONE 2014, 9. [CrossRef] [PubMed]

233. González-Schain, N.; Dreni, L.; Lawas, L.M.F.; Galbiati, M.; Colombo, L.; Heuer, S.; Jagadish, K.S.V.; Kater, M.M. Genome-wide transcriptome analysis during anthesis reveals new insights into the molecular basis of heat stress responses in tolerant and sensitive rice varieties. Plant Cell Physiol. 2016, 57, 57-68. [CrossRef] [PubMed]

234. Kumar, R.; Lavania, D.; Singh, A.K.; Negi, M.; Siddiqui, M.H.; Al-Whaibi, M.H.; Grover, A. Identification and characterization of a small heat shock protein 17.9-CII gene from faba bean (Vicia faba L.). Acta Physiol. Plant. 2015, 37. [CrossRef]

235. Zhang, X.; Wang, J.; Huang, J.; Lan, H.; Wang, C.; Yin, C.; Wu, Y.; Tang, H.; Qian, Q.; Li, J.; et al. Rare allele of OsPPKL1 associated with grain length causes extra-large grain and a significant yield increase in rice. Proc. Natl. Acad. Sci. USA 2012, 109, 21534-21539. [CrossRef] [PubMed]

236. Iovieno, P.; Punzo, P.; Guida, G.; Mistretta, C.; Van Oosten, M.J.; Nurcato, R.; Bostan, H.; Colantuono, C.; Costa, A.; Bagnaresi, P.; et al. Transcriptomic changes drive physiological responses to progressive drought stress and rehydration in tomato. Front. Plant Sci. 2016, 7, 1-14. [CrossRef] [PubMed]

237. Shi, J.; Yan, B.; Lou, X.; Ma, H.; Ruan, S. Comparative transcriptome analysis reveals the transcriptional alterations in heat-resistant and heat-sensitive sweet maize (Zea mays L.) varieties under heat stress. BMC Plant Biol. 2017, 17, 26. [CrossRef] [PubMed]

238. Chen, S.; Li, H. Heat Stress Regulates the Expression of Genes at Transcriptional and Post-Transcriptional Levels, Revealed by RNA-seq in Brachypodium distachyon. Front. Plant Sci. 2017, 7, 1-13. [CrossRef] [PubMed]

239. Jia, J.; Zhou, J.; Shi, W.; Cao, X.; Luo, J.; Polle, A.; Luo, Z. Bin Comparative transcriptomic analysis reveals the roles of overlapping heat-/drought-responsive genes in poplars exposed to high temperature and drought. Sci. Rep. 2017, 7, 1-17. [CrossRef]

240. Kosová, K.; Vítámvás, P.; Prášil, I.T.; Renaut, J. Changes under abiotic stress-Contribution of proteomics studies to understanding plant stress response. J. Proteomics 2011, 74, 1301-1322. [CrossRef] [PubMed]

241. Rathi, D.; Gayen, D.; Gayali, S.; Chakraborty, S.; Chakraborty, N. Legume proteomics: Progress, prospects, and challenges. Proteomics 2016, 16, 310-327. [CrossRef] [PubMed] 
242. Das, A.; Eldakak, M.; Paudel, B.; Kim, D.W.; Hemmati, H.; Basu, C.; Rohila, J.S. Leaf proteome analysis reveals prospective drought and heat stress response mechanisms in soybean. Biomed Res. Int. 2016, 2016. [CrossRef] [PubMed]

243. Valdés-López, O.; Batek, J.; Gomez-Hernandez, N.; Nguyen, C.T.; Isidra-Arellano, M.C.; Zhang, N.; Joshi, T.; Xu, D.; Hixson, K.K.; Weitz, K.K.; et al. Soybean roots grown under heat stress show global changes in their transcriptional and proteomic profiles. Front. Plant Sci. 2016, 7, 517. [CrossRef] [PubMed]

244. Zhou, S.; Sauvé, R.J.; Liu, Z.; Reddy, S.; Bhatti, S. Heat-induced Proteome Changes in Tomato Leaves. J. Am. Soc. Hortic. Sci. 2012, 136, 2012. [CrossRef]

245. Keller, M.; Consortium, S.; Simm, S. The coupling of transcriptome and proteome adaptation during development and heat stress response of tomato pollen. BMC Genom. 2018, 447. [CrossRef] [PubMed]

246. Sang, Q.; Shan, X.; An, Y.; Shu, S.; Sun, J.; Guo, S. Proteomic analysis reveals the positive effect of exogenous spermidine in tomato seedlings' response to high-temperature stress. Front. Plant Sci. 2017, 8, 120. [CrossRef] [PubMed]

247. Lin, H.H.; Lin, K.H.; Syu, J.Y.; Tang, S.Y.; Lo, H.F. Physiological and proteomic analysis in two wild tomato lines under waterlogging and high temperature stress. J. Plant Biochem. Biotechnol. 2016, 25, 87-96. [CrossRef]

248. Wienkoop, S.; Morgenthal, K.; Wolschin, F.; Scholz, M.; Selbig, J.; Weckwerth, W. Integration of metabolomic and proteomic phenotypes. Mol. Cell. Proteom. 2008, 7, 1725-1736. [CrossRef] [PubMed]

249. Caldana, C.; Degenkolbe, T.; Cuadros-Inostroza, A.; Klie, S.; Sulpice, R.; Leisse, A.; Steinhauser, D.; Fernie, A.R.; Willmitzer, L.; Hannah, M.A. High-density kinetic analysis of the metabolomic and transcriptomic response of Arabidopsis to eight environmental conditions. Plant J. 2011, 67, 869-884. [CrossRef] [PubMed]

250. De Block, M.; Verduyn, C.; De Brouwer, D.; Cornelissen, M. Poly(ADP-ribose) polymerase in plants affects energy homeotasis, cell death and stress tolerance. Plant J. 2005, 41, 95-106. [CrossRef] [PubMed]

251. Maruyama, K.; Takeda, M.; Kidokoro, S.; Yamada, K.; Sakuma, Y.; Urano, K.; Fujita, M.; Yoshiwara, K.; Matsukura, S.; Morishita, Y.; et al. Metabolic pathways involved in cold acclimation identified by integrated analysis of metabolites and transcripts regulated by DREB1A and DREB2A. Plant Physiol. 2009, 150, 1972-1980. [CrossRef] [PubMed]

252. Crisp, P.A.; Ganguly, D.; Eichten, S.R.; Borevitz, J.O.; Pogson, B.J. Reconsidering plant memory: Intersections between stress recovery, RNA turnover, and epigenetics. Sci. Adv. 2016, 2. [CrossRef] [PubMed]

253. Liu, J.; Feng, L.; Li, J.; He, Z. Genetic and epigenetic control of plant heat responses. Front. Plant Sci. 2015, 6, 267. [CrossRef] [PubMed]

254. Gardiner, L.-J.; Quinton-Tulloch, M.; Olohan, L.; Price, J.; Hall, N.; Hall, A. A genome-wide survey of DNA methylation in hexaploid wheat. Genome Biol. 2015, 16, 273. [CrossRef] [PubMed]

255. Chinnusamy, V.; Zhu, J.K. Epigenetic regulation of stress responses in plants. Curr. Opin. Plant. Biol. 2009, 12, 133-139. [CrossRef] [PubMed]

256. Ganguly, D.; Crisp, P.A.; Eichten, S.R.; Pogson, B.J. The Arabidopsis DNA methylome is stable under transgenerational drought stress. Plant. Physiol. 2017, 175. [CrossRef] [PubMed]

257. Sanchez, D.H.; Paszkowski, J. Heat-induced release of epigenetic silencing reveals the concealed role of an imprinted plant gene. PLoS Genet. 2014, 10. [CrossRef] [PubMed]

258. Gao, G.; Li, J.; Li, H.; Li, F.; Xu, K.; Yan, G.; Chen, B.; Qiao, J.; Wu, X. Comparison of the heat stress induced variations in DNA methylation between heat-tolerant and heat-sensitive rapeseed seedlings. Breed. Sci. 2014, 64, 125-133. [CrossRef] [PubMed]

259. Li, J.; Huang, Q.; Sun, M.; Zhang, T.; Li, H.; Chen, B.; Xu, K.; Gao, G.; Li, F.; Yan, G.; et al. Global DNA methylation variations after short-term heat shock treatment in cultured microspores of Brassica napus cv. Topas. Sci. Rep. 2016, 6. [CrossRef] [PubMed]

260. Mizuguchi, G.; Shen, X.; Landry, J.; Wu, W.H.; Sen, S.; Wu, C. ATP-driven exchange of histone H2AZ variant catalyzed by SWR1 chromatin remodeling complex. Science. 2004, 303, 343-348. [CrossRef] [PubMed]

261. Lu, P.Y.T.; Lévesque, N.; Kobor, M.S. NuA4 and SWR1-C: Two chromatin-modifying complexes with overlapping functions and components. Biochem. Cell. Biol. 2009, 87, 799-815. [CrossRef] [PubMed]

262. Choi, K.; Zhao, X.; Kelly, K.A.; Venn, O.; Higgins, J.D.; Yelina, N.E.; Hardcastle, T.J.; Ziolkowski, P.A.; Copenhaver, G.P.; Franklin, F.C.H.; et al. Arabidopsis meiotic crossover hot spots overlap with H2A.Z nucleosomes at gene promoters. Nat. Genet. 2013, 45, 1327-1338. [CrossRef] [PubMed] 
263. Zilberman, D.; Coleman-Derr, D.; Ballinger, T.; Henikoff, S. Histone H2A.Z and DNA methylation are mutually antagonistic chromatin marks. Nature 2008, 456, 125-129. [CrossRef] [PubMed]

264. Kumar, S.V.; Wigge, P.A. H2A.Z-Containing nucleosomes mediate the thermosensory response in Arabidopsis. Cell 2010, 140, 136-147. [CrossRef] [PubMed]

265. March-Díaz, R.; Reyes, J.C. The beauty of being a variant: H2A.Z and the SWR1 complex in plants. Mol. Plant. 2009, 2, 565-577. [CrossRef] [PubMed]

266. Ni, Z.; Li, H.; Zhao, Y.; Peng, H.; Hu, Z.; Xin, M.; Sun, Q. Genetic improvement of heat tolerance in wheat: Recent progress in understanding the underlying molecular mechanisms. Crop. J. 2018, 6, 32-41. [CrossRef]

267. Kumar, R.R.; Pathak, H.; Sharma, S.K.; Kala, Y.K.; Nirjal, M.K.; Singh, G.P.; Goswami, S.; Rai, R.D. Novel and conserved heat-responsive microRNAs in wheat (Triticum aestivum L.). Funct. Integr. Genom. 2015, 15, 323-348. [CrossRef] [PubMed]

268. Charon, C.; Moreno, A.B.; Bardou, F.; Crespi, M. Non-protein-coding RNAs and their interacting RNA-binding proteins in the plant cell nucleus. Mol. Plant. 2010, 3, 729-739. [CrossRef] [PubMed]

269. Xin, M.; Wang, Y.; Yao, Y.; Song, N.; Hu, Z.; Qin, D.; Xie, C.; Peng, H.; Ni, Z.; Sun, Q. Identification and characterization of wheat long non-protein coding RNAs responsive to powdery mildew infection and heat stress by using microarray analysis and SBS sequencing. BMC Plant. Biol. 2011, 11. [CrossRef] [PubMed]

270. Xin, M.; Wang, Y.; Yao, Y.; Xie, C.; Peng, H.; Ni, Z.; Sun, Q. Diverse set of microRNAs are responsive to powdery mildew infection and heat stress in wheat (Triticum aestivum L.). BMC Plant. Biol 2010, 10, 123. [CrossRef] [PubMed]

271. Giusti, L.; Mica, E.; Bertolini, E.; De Leonardis, A.M.; Faccioli, P.; Cattivelli, L.; Crosatti, C. microRNAs differentially modulated in response to heat and drought stress in durum wheat cultivars with contrasting water use efficiency. Funct. Integr. Genom. 2017, 17, 293-309. [CrossRef] [PubMed]

272. Wang, Y.; Sun, F.; Cao, H.; Peng, H.; Ni, Z.; Sun, Q.; Yao, Y. TamiR159 Directed Wheat TaGAMYB cleavage and its involvement in anther development and heat response. PLoS ONE 2012, 7. [CrossRef] [PubMed]

273. Abdelrahman, M.; Al-Sadi, A.M.; Pour-Aboughadareh, A.; Burritt, D.J.; Tran, L.S.P. Genome editing using CRISPR/Cas9-targeted mutagenesis: An opportunity for yield improvements of crop plants grown under environmental stresses. Plant. Physiol. Biochem. 2018. [CrossRef] [PubMed]

274. Abdallah, N.A.; Prakash, C.S.; McHughen, A.G. Genome editing for crop improvement: Challenges and opportunities. GM Crops Food 2015, 6, 183-205. [CrossRef] [PubMed]

275. Zhu, C.; Bortesi, L.; Baysal, C.; Twyman, R.M.; Fischer, R.; Capell, T.; Schillberg, S.; Christou, P. Characteristics of genome editing mutations in cereal crops. Trends Plant. Sci. 2017, 22, 38-52. [CrossRef] [PubMed]

276. Osakabe, Y.; Watanabe, T.; Sugano, S.S.; Ueta, R.; Ishihara, R.; Shinozaki, K.; Osakabe, K. Optimization of CRISPR/Cas9 genome editing to modify abiotic stress responses in plants. Sci. Rep. 2016, 6. [CrossRef] [PubMed]

277. Zhou, H.; He, M.; Li, J.; Chen, L.; Huang, Z.; Zheng, S.; Zhu, L.; Ni, E.; Jiang, D.; Zhao, B.; et al. Development of commercial thermo-sensitive genic male sterile rice accelerates hybrid rice breeding using the CRISPR/Cas9-mediated TMS5 editing system. Sci. Rep. 2016, 6. [CrossRef] [PubMed]

278. Klap, C.; Yeshayahou, E.; Bolger, A.M.; Arazi, T.; Gupta, S.K.; Shabtai, S.; Usadel, B.; Salts, Y.; Barg, R. Tomato facultative parthenocarpy results from SIAGAMOUS-LIKE 6 loss of function. Plant. Biotechnol. J. 2017, 15, 634-647. [CrossRef] [PubMed]

(C) 2018 by the authors. Licensee MDPI, Basel, Switzerland. This article is an open access article distributed under the terms and conditions of the Creative Commons Attribution (CC BY) license (http:/ / creativecommons.org/licenses/by/4.0/). 